\title{
SILURIAN CONTINENTAL DISTRIBUTIONS, PALEOGEOGRAPHY, CLIMATOLOGY, AND BIOGEOGRAPHY
}

\author{
A.M. ZIEGLER ${ }^{1}$, K.S. HANSEN ${ }^{1}$, M.E. JOHNSON ${ }^{1}$, M.A. KELLY ${ }^{1}$, \\ C.R. SCOTESE ${ }^{2}$ and R. VAN DER VOO ${ }^{3}$ \\ ${ }^{1}$ Department of Geophysical Sciences, The University of Chicago, Chicago, Ill. (U.S.A.) \\ 2 Department of Geology, The University of Illinois, Chicago Circle, Chicago, Ill. \\ (U.S.A.) \\ ${ }^{3}$ Department of Geology and Mineralogy, The University of Michigan, Ann Arbor, Mich. \\ (U.S.A.)
}

(Received November 2, 1976)

\section{ABSTRACT}

Ziegler, A.M., Hansen, K.S., Johnson, M.E., Kelly, M.A., Scotese, C.R. and Van der Voo, R., 1977. Silurian continental distributions, paleogeography, climatology, and biogeography. In: M.W. McElhinny (editor), The Past Distribution of Continents. Tectonophysics, $40: 13-51$.

Continental orientations during the Silurian Period have been determined using paleoclimatic in addition to paleomagnetic data. The influence of climate on lithology is particularly marked during periods like the Silurian when epeiric seas were widespread and sedimentation was dominantly autoch thonous (evaporites, carbonates, reefs, authigenic minerals) and therefore reflective of climate at the depositional site. During such times, with few large land areas in low latitudes, one would expect climatic patterns to have been more zonal than cellular, and also that long river systems (capable of transporting clastic sediments from wet to dry belts) would not have existed. Therefore, even alloch thonous deposits, particularly thick sequences of coarse clastics can be added to the list of paleoclimatic indicators.

Silurian northern hemisphere atmospheric circulation can be modeled on present patterns in the southern hemisphere because of the lack of significant land influence on climate. The wethot $\left(10^{\circ} \mathrm{N}-10^{\circ} \mathrm{S}\right)$, dry-warm $\left(10^{\circ}-30^{\circ}\right)$, wet-cool $\left(30^{\circ}-60^{\circ}\right)$, dry-cold $\left(60^{\circ}\right.$-pole) pattern is amply confirmed by Silurian sediment distribution on those paleocontinents whose orientations have been established from paleomagnetic measurements (Laurentia, Baltica, Siberia). Paleozoic sedimentation in these zones is as follows: $10^{\circ} \mathrm{N}-$ $10^{\circ} \mathrm{S}$, thick clastics and reefs associated with leading plate margins, and carbonates and reefs in the epeiric seas; $10^{\circ}-30^{\circ}$, evaporites, carbonates and reefs; $30^{\circ}-60^{\circ}$, clastics, coals and tillites; $60^{\circ}$-pole mostly tillites. The other paleo-continents (Kazakhstania, North China, South China, Gondwana) can be oriented by using the above lithologic associations in ways consistent with their known convergent and collision patterns in the late Paleozoic. All were in relatively low latitudes with the exception of Gondwana which was over the South Pole. A large north polar ocean existed which must have had an ameliorating effect on climate in the nurthern hernisphere, while the oppusite was true of the southern hemisphere.

The conclusion that most paleocontinents had extensive epeiric seas and were positioned in low latitudes accounts for the cosmopolitan nature of Silurian faunas. Only Gondwana in the south (Clarkeia fauna), and Mongolia in the north (Tuvaella fauna) 
shows signs of provincialism and low faunal diversities. This situation can be contrasted with the Devonian, when the collision of Laurentia and Baltica resulted in land barriers and marked provincialism.

\section{INTRODUCTION}

The object of this paper is to reconstruct in some detail the conditions during the early part of the Silurian Period (approximately 440 million years ago). This was prior to any of the Paleozoic continental collisions which led to the assembly of Pangaea, but after a time of marked continental isolation, when faunas were provincial. Silurian faunas are relatively cosmopolitan, and this allows for accurate correlation which greatly facilitates paleogeographic reconstructions. Ideally, it is best to unravel the complete history of plate evolution back to the period of paleogeographic interest. To do this for the Paleozoic is a formidable task, and what is herein attempted is a more precise delineation of past continental margins. It is now possible to represent sutures as belts, rather than lines, because it is now realized that thick flysch wedges have been accreted to many continental margins along compressive plate boundaries (Seeley et al., 1974). The Mesozoic and Cenozoic additions are irrelevant to Pangaean fits, and these and the Upper Paleozoic additions are irrelevant to Silurian paleogeography. Therefore we have tried to identify as many of these later additions as possible, and in the following paragraphs we set out criteria for recognition of modifications to continental outlines, firstly for extensional or passive margins, and secondly for compressive margins.

Extensional margins have prominent scarps, owing to their rifting history; the classic "Bullard Fit" of the Atlantic bordering continents was based on such margins (Bullard et al., 1965). However, defining the margin of a continent on the basis of a single bathymetric contour results in including areas formed through delta building and volcanic activity, and more significantly, in excluding large areas of deeply subsided continental crust, such as the Rockall Plateau (Scrutton and Roberts, 1971), and the $1900 \mathrm{~km}$ long area east of the southern tip of South America (see Uchupi, 1971). Our solution has been to determine the continental slope/continental rise junction for the extensional margins of the Atlantic and Indian Oceans from the detailed bathymetric atlases of Uchupi (1971) and Udintsev (1975). This solution tends to ignore the extensional effects of the graben which are abundant along the Atlantic margins (see the many cross-sections in Nairn and Stehli, $1973,1974)$. For narrow seas such as the Red Sea, the scarps are on shore, and the best fit of Africa and the Arabian Peninsula is obtained by fitting these and ignoring the volcanic additions of the Afar Depression (McKenzie et al., 1970).

The compressional plate boundaries are the main sites of continental accretion, and recent symposium volumes on Pacific type margins (Coleman, 1973; Burk and Drake, 1974; Spencer, 1974) contain many modern 
examples. Much of the direct evidence lies seaward of the volcanic chains or buried beneath alluvial plains, and was elucidated initially through oil company geophysical work. Interpretive models differ in detail (Bogdanov, 1973; Scholl, 1974; Seeley et al., 1974) but all agree that ocean floor and trench deposits are being wedged against the continental margins above subduction zones as plates converge. Frequently, ophiolites are prominent along the inner boundary of these accretionary flysch wedges and these evidently represent an early phase of convergence prior to formation of mountains of sufficient height to provide the trench sediments which then dominate the accretionary wedge. The widest accretionary belts occur in the tropics and the temperate zones where the rainfall is sufficient to erode the sediments to fill the trenches. This accretionary process is also evident in Paleozoic rocks (Peive et al., 1972; Mossakovskiy, 1970; Ziegler, 1970, 1972), and such zones include many of the classic eugeosynclines. The sequences contain the modern oceanic lithologies; spilites, cherts (lydites), shales, and turbidites containing clasts of the above rock types, plus much debris from andesitic volcanoes. These rocks, once folded, may be covered by thick piles of andesitic lava (the "Orogenic Stage" of Soviet terminology), and eventually become part of the continent.

As ocean consumption proceeds, continental collisions may result, and the best preserved examples of this are to be found in central Asia, the site of many compressional boundaries which were active during large portions of the Paleozoic. Here, the ancient continents of Baltica, Kazkhstania, Siberia, and others seem to have "touched" without becoming severely overthrust, and the "ophiolites are of decreasing age from the edges of eugeosynclinal zones toward their centres" (Zonenshain, 1973, p. 213). Ideally, therefore, the youngest ophiolite should be used to mark the suture between collided continents. In many areas, however, we have had to rely on volcanic polarity (Kuno, 1966), metamorphic polarity (Coleman, 1972), or simply on marked discontinuities in sedimentary facies, to locate sutures.

One would expect that when continents of irregular shape collide, gaps would remain in some areas, and it is important to locate these to better delineate the original continental margins. For instance, the North Caspian Depression, an area of $750 \mathrm{~km}$ by $450 \mathrm{~km}$ seems to be founded on oceanic basement and contains up to $25 \mathrm{~km}$ of sediment (Garetsky et al., 1972). Other such areas in Asia are known (Khalevin, 1972; Yegorkin and Matushkin, 1970) and more will probably be discovered as deep seismic profiling progresses.

In the following sections we first discuss the modifications to continental margins during the Mesozoic and Cenozoic and then the modifications of the Upper Paleozoic (Fig. $1 *$ ). It must be stressed that Fig. 1 differs in some important respects from current tectonic maps. Most tectonic maps delineate orogenic zones on the basis of the youngest orogeny affecting the zone,

* See fold-out pages 33 and 34 . 
whereas our map, by contrast, indicates the initial folding of an orogen, and for that, only the portion that can be reliably determined to have been deposited on oceanic crust. Mainly allochthonous occurrences of beds originally deposited on oceanic crust, such as many of the Alpine nappes, have also been left out. The net result is a map that shows fold zones in a far more restricted sense than is traditional, and we feel that the folding that has affected the margins of the paleo-continents has not, in most cases, significantly distorted their outlines.

\section{MESOZOIC TO PRESENT CONTINENTAL MARGINS}

\section{The Americas, Europe, Africa, and the Atlantic Ocean}

The margins of the Atlantic Ocean are essentially unmodified since the breakup of Pangaea except for local delta building and volcanism, and the continental slope/continental rise junction for most segments can be readily cietermined from Uchupi's atlas (1971). However, the fits are quite ambiguous, except for the Africa-South America pair, and it seems that the often quoted Bullard Fit (Bullard et al., 1965) is incorrect with respect to the Greenland-Europe pair, and the North America-Africa pair. The Norwegian Sea fit of Bott and Watts (1971) is preferred because it gives continuity to the Caledonian front from Scotland and the Faeroes to Greenland. The central Atlantic fit of Van der Voo et al. (1976) has the three-fold advantage of superimposing the Pangaean paleomagnetic poles, of completely closing the Gulf of Mexico, and of aligning the unfolded Lower Paleozoic rocks of the Florida Platform (Pojeta et al., 1976) with similar rocks of Portugese Guinea (Rodgers, 1972, p. 278). The Bullard Fit is unlikely because it places the Paleozoic Mauritanide fold belt of West Africa adjacent to Florida instead of the Appalachian fold belt. Each of these readjustments amounts to only a few hundred kilometres, but the rotation imposed on the Pangaean extremities is considerable.

\section{North and South America, and the Gulf of Mexico and Carribbean Sea}

Unlike the Atlantic, the areas between North America and South America have been profoundly altered in several ways: by island-arc volcanism in the Lesser Antilles and the Panamanian Isthmus; by accretionary flysch wedges in the Greater Antilles and northwestern South America; by sedimentary infill in the Gulf of Mexico; by left-lateral transcurrent faulting between Mexico and Honduras; and by widespread Mesozoic folding in Mexico. We believe that the plate-tectonics outline of this region provided by Malfait and Dinkelman (1972) is essentially correct. We assume the margin of North America to be the Cretaceous reef tract, which strikes inland at the Mississippi Delta and roughly parallels the coast some 100-200 km inland through Texas and Mexico (Martin and Case, 1975, p. 67). Mexico must have rotated counter-clockwise to produce the Mesozoic fold belt along the Sierra Madre Oriental, but for convenience in contructing the base maps we rotate 
Mexico along the Torreon-Monterrey Shear Zone (De Cserna, 1970). The same sense of movement is displayed along the Polochic Fault (Viniegra, 1971), in which Honduras and adjacent areas are being currently transported eastward into the Carribbean, while the Yucatan Platform (Viniegra, 1971) seems to have come from the north during the initial spreading phase, to judge by east-northeast trending magnetic anomalies in the northern Gulf region (Yungul, 1971). South America is the only other area of importance in refitting the Americas and it appears to have been accreted to west of the Guayaquil and Dolores Faults of Ecuador and Columbia (Campbell, 1974a, $1974 \mathrm{~b}$ ), and extended along its northern perimeter as indicated by numerous graben along the coast of Venezuela (Case, 1974).

Eurasia, Africa, India, and the Tethys

Tethys is the most recent ocean to have closed, but at the same time is one of the most complicated and difficult regions of the world to understand. Very little new terrain appears to have been added to the continents of this region since the late Paleozoic, although the remnants of late Paleozoic Tethys, that is the Mediterranean, Black Sea, and southern Caspian Sea, have been partially filled by delta progradation. We believe that the paucity of accretionary flysch wedges is indirectly due to the dry climate associated with the north tropic. Evaporite conditions existed in Europe during the Permian, and as Europe, Tethys and Africa moved north beneath the tropic (Smith et al., 1973), the dry conditions affected the Tethys in the Mesozoic, and more recently Africa. This may account for why the various volcanic chains and the Hercynian Mountains of Central Europe failed to provide thick clastics during the Triassic and Jurassic. In rainy equatorial regions, such as southeast Asia, the thick clastic wedges deposited on the ocean floor occur as a buffer zone between collided plates. These clastic wedges are rare in the Alpine System and the pelagic veneer of the Tethys now rests in allochthonous sheets on top of continental fragments that have ground together in complicated fashions.

Much information relevant to the plate evolution of Tethys has been summarized by Dewey et al. (1973). These authors recognize about two dozen microplates in the Mediterranean vicinity alone. The western Mediterranean is relatively straightforward where counter-clockwise rotations of the microplates have been demonstrated by paleomagnetic research (Zijderveld and Van der Voo, 1973). These plates are the Iberian Peninsula, Corsica and Sardinia, and Italy, including the Southern Alps, and these fit satisfactorily when rotated back against southern Europe. The situation in the eastern Mediterranean is far more difficult, and we have simply selected two of the most important sutures, the Carpathians on the north, and the modern compressive plate boundary in the Mediterranean on the south, to delineate a probably heterogeneous area which includes virtually all of southeastern Europe. Some authors regard the prominent ophiolite belts of the Hellenides and Dinarides as an important suture, but this may simply 
represent one of many small ocean basins formed during the breakup of Pangaea. Farther to the east, the late Paleozoic Tethys extended north of Iran, Afghanistan and India. These areas can be related to Arabia and Gondwana by paleomagnetic or stratigraphic commonality (Becker et al., 1973; Stocklin, 1974). There is a Cretaceous--Paleogene eugeosyncline between Iran and Afghanistan (Kulakov, 1970) and Iran was separated from the Arabian Peninsula along the Zagros suture during the Mesozoic (Stocklin, 1974), so movement of these pieces relative to each other, and to India is uncertain. The northerly margins of the Indian subcontinent are defined by the Indus Suture along which occur areas of Cretaceous and Tertiary accretionary flysch wedges (Stoneley, 1974).

\section{Africa, India, Australia, Antarctica, and the Indian Ocean}

As in the case of the Atlantic, the margins of the continents bounding the Indian Ocean have been drawn at the continental slope/continental rise junction. This can readily be determined from the bathymetric atlas of Udintsev (1975), and good morphological fits are obtained for India and Australia to Antarctica. The relation of this group to Africa, however, is uncertain and we follow the plate-tectonics interpretation of Laughton et al. (1973) which places India adjacent to Madagascar, and Madagascar against Kenya, as would seem to be required by paleomagnetic information (McElhinny et al., 1976). The only area of Mesozoic to Cenozoic continental accretion associated with the Indian plate is a wide belt extending through western Burma, southwest Sumatra, Java and southeast Borneo to the south of the Gumai-GarbaAtjeh Line and the Meratus-Bobaris Line (Hutchinson, 1975).

North China, South China, Indo-China, Malaysia and the Tsin Ling Geosyncline

These paleo-continents closed in the Triassic to complete the assembly of Pangaea. Burrett (1974) has brought together many of the facts relevant to the plate boundaries in this part of the world. He links together much of China south of the North Chinese block on the basis of faunal similarities in the Lower Paleozoic, but admits that the timing of the folding is best accounted for by the Yangtzi paraplatform of southeastern China having acted as a separate block through Triassic times. Southwest of South China, and separating this from much of Indo-China, is the Kon Voi Sutural Zone of North Vietnam (Din'Kat, 1972) which contains Triassic ultramafics (Izokh and Van Tien, 1964). This can be traced along the western side of South China to western Yunnan where a Triassic geosyncline was deformed toward the end of that period (Burrett, 1974, p. 184). We connect this zone with the Tsin Ling geosyncline along the north of South China where T'riassic geosynclinal rocks also occur (Jiang and Chu, 1964) and from there to the Okcheon Geosynciine of the same age in southern Korea (Lee, 1972, 
p. 82). Finally, the Chichibu Geosyncline of Japan (Kimura, 1974) could be a further continuation of the same zone. Thus, South China, including South Korea and southeastern Japan, seem to have collided with both Asia and Indo-China in the Triassic, but still another plate, Malaysia, was involved in the assembly at about the same time. Malaysia closed with Indo-China along the Dien Bien Sutural zone of North Vietnam, which has been interpreted as of strike-slip type (Din'Kat, 1972, p. 937). Burrett (1974, p. 184) has pointed out, however, that all of Paleozoic Southeast Asia is similar faunally to the Yangtzi Paraplatform and suggests that the sutural zones of North Vietnam may represent narrow ocean basins.

\section{Asia, Oceania, and the western Pacific Ocean}

Mesozoic to Cenozoic accretionary flysch wedges are prominent along the western margin of the Pacific adjacent to land areas with high enough rainfall to erode and transport the fill for the trenches. In the south temperate zone is the Artearoa Eugeosyncline of New Zealand (Kingma, 1974, p. 104). In the equatorial zone are the North New Guinea eugeosyncline (Visser and Loffler, 1975, p. 373), the Philippines (Rutland and Walter, 1974), and Taiwan (Murphy, 1973). The north temperate zone contains the Shimato Major Belt of coastal Japan (Ichikawa, 1965, p. 127), the Sikhote-Alin Synclinorium (Bobylev and Solov'yev, 1971, p. 397), and the eastern portion of Kamchatka (Belyi, 1973, p. 256). The contemporary island arcs are both numerous and obvious and these are also included in Fig. 1. Significant spreading of older terrains from their Pangaean positions is evident in the case of New Zealand and Japan, and we have refitted these against Australia (Packham, 1973, p. 376) and Asia (Hilde and Wageman, 1973, p. 431), respectively.

\section{Asia, Kolyma, North America, and the Arctic Ocean}

Churkin (1972) has pointed out that the suture between North America and Siberia does not lie at the Bering Strait, and drew the line several thousand kilometers inland in Asia along the Verkhoyansk Mountains. However, it has been postulated that this wide mountain belt is of décollement origin and rests on a sole of Devonian evaporites associated with the Siberian platform (Sborshcikov and Natapov, 1968). Therefore we draw the sutural zone east of the Verkhoyansk Mountains along the margin of the Kolyma Massif, an ancient platform which is bounded on the southwest and north by a fold belt of Paleozoic geosynclinal rocks (Churkin, 1972). In addition, the Kolyma Massif is bounded on the east by the South Anyui Sutural Trough which closed in the late Mesozoic (Seslavinskiy, 1970), indicating that this massif may not originally have been closely associated with either the Siberian or North American Plates. Herron et al. (1974), suggested that the Kolyma Massif drifted across the Arctic Ocean and collided with northern 
Canada during the early Paleozoic to cause the Franklinian orogeny and then separated and drifted to its present position. We do not favor this proposal because Kolyma was a carbonate platform in the early and mid-Paleozoic with no hint of a thick clastic wedge and because the margins of this part of the Arctic Ocean are morphologically unlike rifted Atlantic-type margins.

\section{The Americas, Antarctica, and the eastern Pacific Ocean}

As in the case of the western Pacific, Mesozoic to Cenozoic accretionary flysch wedges are prominent and are correlated with climate. North temperate accretion is especially evident in North America from the Bering Sea (Moore, 1974, p. 814) to the Gulf of Alaska (Lathram et al., 1974, p. 570) and along the western margin of the United States (Burchfiel and Davis, 1972, p. 104). Equatorial zone accretion occurs from the Isthmus of Panama to Ecuador, as has been mentioned in the section on the Caribbean, and along the coast of Peru (Cobbing, 1972, p. 308). Finally, south temperate accretion has apparently occurred in the northern part of the Antarctic Peninsula (Adie, 1972).

\section{MIDDLE AND UPPER PALEOZOIC CONTINEN'TAL MARGINS}

\section{Laurentia, Baltica, Barentia and the Iapetus Ocean}

The Iapetus (Harland and Gayer, 1972) or Proto-Atlantic Ocean closed during the late Silurian and early Devonian (McKerrow and Ziegler, 1972b), so in our map (Fig. 1) no accretionary zones are shown. This paleo-ocean can be traced in the Northern Appalachians from New England through the Fredericton Trough of New Brunswick (McKerrow and Ziegler, 1971) and across central Newfoundland (McKerrow and Ziegler, 1972a). In Britain, the corresponding Caledonian suture must go between the Southern Uplands of Scotland and the English Lake District, the youngest part of the ocean (Ziegler, 1970, 1972), and in Norway, allochthonous blocks containing Ordovician North American faunas occur in the Trondheim Region (Gee, 1975), so the suture must parallel the Norwegian Coast. From here, the Caledonian belt may curve around the north of Norway to the vicinity of Novaya Zemlya (Emelyanov et al., 1971, p. 6). Between Norway and the Barents Craton, sediments are between seven and thirteen kilometers thick (Aam, 1975, p. 371) and may rest on oceanic basement. This marked sediment-filled trough may indicate incomplete closure of the Iapetus Ocean. Caledonian folding occurs in the Spitsbergen portion of the Barents Craton and in adjacent parts of Greenland (Haller, 1971, p. 135) but there are apparently no true oceanic rocks in these areas and it is possible that the Barents craton was an extension of the North American-Greenland Craton in early Paleozoic times. 


\section{Eur-America, Kazakhstania, and the Uralian Geosyncline}

Eur-America was formed by the collision of Baltica and Laurentia; Kazakhstania is a newly defined Paleozoic continent to the east of the Urals (Zonenshain, 1973, p. 215); and the term, Pleionic Ocean, was proposed for the ocean represented by the Uralian Geosyncline (McKerrow and Ziegler, $1972 b)$. Burrett $(1974$, p. 182) drew the suture in a covered area well to the east of the Urals, but we prefer to draw it along the zone of youngest ophiolites in the axial part of the southern Urals. These are of lower Carboniferous age and are flanked both to the east and west by a succession of older fold zones of Devonian and late Silurian age "in transition stage from oceanic to continental" (Ivanov et al., 1975, p. 107). The fact that this ocean should begin to close at the same time as the collision along the Iapetus Ocean is perhaps more than a coincidence. The margins of EurAmerica and Kazakhstania have been traced by deep seismic sounding both to the southwest in the region of the Aral and Caspian Seas, and to the northwest in the West Siberian Lowlands (Khalevin, 1972) and several large areas interpreted as oceanic crust seem to have been left by incomplete closure. In other areas, many deep boreholes have encountered Paleozoic and Precambrian rocks north and west of Kazakhstan (Kulikov, 1970; Vinogradov, 1968, 1969). Facies continuity suggests that these areas belong to Kazakhstania, and that the suture does indeed go through the axial part of the southern Urals.

Kazakhstania, Siberia, South Gobi, and the Irtysch-South Mongolian Oceanic Basin

These continents, and the ages of ophiolites in the continuous "oceanic basin" between Siberia on the north and Kazakhstania and South Gobi on the south have been described by Zonenshain $(1973$, p. 217). As in the case of the Urals, "ophiolites are of decreasing age from the edges of eugeosyncline zone toward their centers" the youngest being of Lower Carboniferous age. Paleozoic andesitic volcanism is abundantly evident along the margins of these paleo-continents and indeed this region would appear to be the equivalent of the modern western Pacific. A complication is the Hercynian Khangai-Khentei Zone (Zonenshain et al., 1971, p. 230) or Tukuringra Geosyncline (Kosygin and Parfenov, 1975, p. 196) which occurs subparallel with, and north of, the South Mongolian eugeosyncline in central Mongolia and southern Siberia. This zone is an anomaly in a pattern of successively younger Precambrian through Paleozoic eugeosynclinal belts along the southern margin of Siberia, and may be an instance of back-arc spreading. The eastward extension of the South Mongolian Ocean through Manchuria is uncertain, though spilites are present in the southeastern-most part of the Soviet Union (Vinogradov, 1968, 1969) and may represent the same ocean. The northwestern continuation of the Irtysch Ocean through the West 
Siberian lowlands is uncertain. This is an area of extensive Triassic graben (Kulikov et al., 1972), and hence unknown post-Paleozoic extension.

The greater Siberia-Kazakhstania continent, North China and the Solonker Zone

As has been reviewed above, the assembly of northern Eurasia was complete by Carboniferous times, but a persistent east-west trending late Paleozoic ocean containing Permian and earlier ophiolites can be traced from the Pamirs (Vinogradov, 1968, 1969), along the southern Tien Shan (Bush et al., 1970), to the Solonker Zone of the southern border of Mongolia (Borzakovskiy and Suyetenko, 1970). Apparently, andesitic volcanism is confined to the northern margin of this ocean while the Precambrian terrains of the Pamirs, the Tarim Platform and the North Chinese Platform occur immediately to the south. The extension of this ocean through Manchuria is purely conjectural; we have simply used the margin of the North Chinese Platform as a guide. Late Paleozoic spilites do occur in Sikhote-Alin, east and northeast of Vladivostok, and may represent a continuation of the Solonker zone.

\section{North China, Tibetia, and the Kunlun Geosyncline}

The Kunlun Geosyncline extends eastward to connect with the Tsin Ling Geosyncline, and northwestward to connect with the continuation of the Solonker zone immediately north of the Pamirs in Tadzhikstan. In the Kunlun, "the principal orogenic movement was early Variscan (Upper Devonian-Lower Carboniferous), and it was this movement that put the life of the geosyncline to an end" (Huang, 1960, p. 509). Therefore, Tibetia seems to have become part of Asia well before South China arrived in the early Mesozoic, as has been shown.

\section{Laurasia, Gondwana, and the Rheic Ocean}

This ocean (McKerrow and Ziegler, 1972b) is to be found within the Appalachian and Hercynian fold systems. Its trace through Mexico is uncertain, but it must go between the Florida Platform, an area of undeformed Paleozoic rocks, and the North American Platform. To the northeast, in the Piedmont, Rankin (1975, p. 298) has suggested that the Brevard Zone is the suture, and we agree that this zone represents the margin of the Paleozoic North American Platform. However, mid-Paleozoic radiumetric dates from areas southeast of the Brevard Zone in the Charlotte Belt (Wright et al., 1975 ) suggest that mountainous terrain was being formed and we believe this area was the source of the clastic wedges of the Appalachian Basin. Provisionally, we include these terrains with North America, and the belt of PanAfrican dates of the Carolina Slate Belt with Gondwana. In the European 
Hercynian belt, we follow Laurent (1972) and Anderson (1975) in the belief that the Culm facies of southwest Fngland, the Sudetides, and the Harz Mountains represent the remnant of the ocean. The same facies is present in the Aljustrel-Sao Domingos Band of southern Portugal (Teixeira and Thadeu, 1967, p. 189) and in Drahany Development of central Czechoslovakia (Chlupac, 1967, p. 119).

\section{Gondwana and the Panthallasan Ocean}

The evidence of late Paleozoic accretionary wedges along the margins of Gondwana that were not involved in collision during the formation of Pangaea is fragmentary. Proceeding in a clockwise direction, there is evidence of a Carboniferous to Permian geosyncline along the northern margin of India in the Mt. Everest vicinity (Chang and Cheng, 1973). All of continental Australia had apparently been built by the Silurian and it has been projected that later accretionary wedges might occur in the subsequently fragmented continental margin of Australia in the Tasman Sea (Packham, 1973), and that these connect with the New Zealand Geosyncline (Waterhouse, 1975). The extension of this marginal geosyncline through Antarctica seems certain, but even the approximate position of terrains that might have been accreted is very difficult. Probably part of west Antarctica and the Antarctic Peninsula were added during the late Paleozoic (see Elliott, 1975, p. 45). These areas have traditionally proved to be awkward for Gondwana reconstructions, and are probably quite irrelevant in such an exercise. In any case, east and west Antarctica seem to be separated by large tracts of oceanic crust (see Rosenberg, 1969) and there may have been movement between the two.

\section{Laurentia and the Panthallasan Ocean}

As in the case of Gondwana, parts of Laurentia that were never subsequently involved in collisions, did accrete some continental material during the late Paleozoic. We have mapped these zones in Alaska, western Canada, and the western United States following Lathram (1973, p. 353) Jones et al. (1972, p. B 212) and Burchfiel and Davis (1972, p. 99), respectively. There are Lower Paleozoic volcanic massifs in southern Alaska and northern California which are seaward of this belt, and these have been interpreted as having been rifted from North America in the late Paleozoic (Churkin, 1974, p. 189).

\section{EARLY SILURIAN CONTINEN'TAL ORIENTATIONS AND PALEOGEOGRAPHY}

\section{Techniques for orienting continents}

The movements of the continents during the Paleozoic have been determined using paleomagnetic, lithologic, biogeographic, geometric and plate- 
tectonic considerations. The paleomagnetic data are few, but adequate to place most major continents in their approximate paleo-latitudes. These latitudinal paths have been checked by examining the distribution of climatically significant lithologies and also faunas of especially high or low diversity. Determining relative longitude has proved more difficult, but arguments concerning faunal connections and timing of known subsequent collisions have proved useful in this connection.

Particular attention in this study has been paid to the distribution of climatically influenced sedimentary rocks. The Silurian was a time of widespread epeiric seas, and so autochthonous deposits, such as carbonates, reefs, evaporites, and authigenic minerals, are abundant and directly reflective of climatic conditions at the depositional site. Predictably, circulation patterns would be more zonal than cellular (see section on Paleoclimatology) during perinds with widespread seas, and hence sedimentary patterns should be diagnostic of paleo-latitudes. As will be seen in the following sections, this prediction is amply confirmed when paleomagnetic data are available. Even the allochthonous clastic deposits seem to be latitudinally restricted to the wet equatorial and temperate regions. During a period like the Silurian one would not expect to have had long river systems, like the Mississippi or Nile, capable of transporting sediments across climatic belts. Clastics then, especially coarse thick deposits associated with leading plate margins, can be used to check plate orientations.

The relation of latitude, climate and sedimentation has been summarized by Briden (1968) and Emery (1969). The equatorial belt is hot and wet and is characterized by thick clastic deposits and reefs in association with active plate margins, and carbonate rocks away from land areas. The tropical belts $\left(10^{\circ}-30^{\circ}\right)$ are warm and dry and it is here that evaporites, carbonates, reefs, and authigenic minerals occur. The temperate zones $\left(30^{\circ}-60^{\circ}\right)$ are cool and rainy and characterized by clastics, including glacial deposits while the polar regions are cold and dry and contain mainly glacial and glacio-marine deposits. Some authors have attached importance to the past distribution of red beds, but since soils are controlled by vegetation, and vegetation patterns have changed through time in ways that are not yet clear, the use of red beds as paleo-latitudinal indicators is dubious.

Caution must also be exercised in evaluating biogeographic data. Traditionally, paleontologists have regarded all faunal differences as being of biogeographic scope, but paleoecologic studies show that many of these may reflect a simple environmental transition. Also, many plants and animals do have remarkable distributive abilities, and in the absence of the prominent north-south land (and sea) barriers which are peculiarly characteristic of the present, it is conceivable that single biogeographic provinces could have circled the earth in the past. Nonetheless, close faunal or floral ties through successive geologic periods would argue for a close longitudinal relationship, and vice versa. 


\section{Paleogeographic technique}

The essence of our technique is to record lithofacies data from rocks that have been reliably dated as Lower Silurian (Llandovery Series) and to estimate the environment of deposition from the communities contained in the rocks. Because Silurian faunas are relatively cosmopolitan, the worldwide correlation of rocks of this period is well established and, moreover, comprehensive summaries of Silurian correlations for many parts of the world are now available (Berry and Boucot, 1970, 1972a, 1972b, 1973; Talent et al., 1975; Ziegler et al., 1974). Areas not covered in these papers, namely Europe and the Soviet Union, have been the subject of detailed paleogeographic analysis recently (Walter, 1972; and Vinogradov, 1968, respectively).

The lithologic data have been assembled from several hundred individual areas around the world and grouped into nine lithofacies. These have been plotted on the Silurian reconstruction (Fig. $2 *$ ). The major sedimentary types have been recorded simply as $(C)$ clastics, $(L)$ carbonates, and $(M)$ mixed clastics and carbonates. The minor sedimentary lithologies recorded are $(E)$ evaporites, $(Q)$ bedded chert (lydite), $(R)$ reefs, and $(Z)$ authigenic minerals, primarily chamosite-hematite ores and related phosphatic nodule beds. The minor lithologies are, of course, usually interbedded with the major ones, but to avoid crowding the map, only one letter is plotted, the minor taking precedence over the major lithology. The volcanic rocks have been grouped

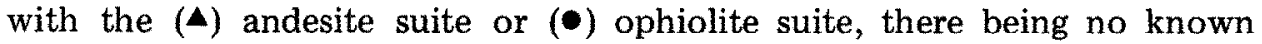
plateau basalts in the Silurian. The andesite suite, or orogenic stage of Soviet terminology, represents the compressive plate boundaries and includes rhyolite (liparite), dacite, basalt, thick pyroclastics, and associated granodiorites, diorites, albitic granite and tonalite. The ophiolite suite, or eugeosynclinal stage of Soviet terminology, represents the extensional plate boundaries and includes spilites, keratophyres, sheeted dikes and gabbros in association with cherts, and other pelagic sedimentary rocks. The volcanic rocks are so important that, for plotting purposes, the volcanic type has been given precedence in mixed volcanic-sedimentary sequences.

The paleogeographic maps show environments for the deep sea, shelf and land areas. The deep-sea environments include ocean floor, represented by the ophiolite suite, and continental slope, characterized by clastics, carbonates, or cherts with abundant slumping and/or mixtures of pelagic and derived shallow cummunities. Of course the deep-sea localities were, in most cases, formed seaward of compressive plate boundaries and these are shown on our map (Fig. 2) slightly displaced from the continents. The shelf has been subdivided into coastal or "Bahamian"-type environments on the one hand, and the more quiet outer shelf or epeiric basins on the other hand, although on the scale used in Fig. 2, we have only been able to show this subdivision on the wider shelves. The former include the Lingula, Eocoelia, Pentamerus and

* See fold-out pages 35 and 36 . 
coral reef communities, while the latter include the Stricklandia and Clorinda communities (Ziegler et al., 1968). In the higher latitudes, benthic communities apparently did not inhabit the outer shelf environments, and in these areas, only the pelagic graptolite fauna occurs (Berry and Boucot, $1972 \mathrm{c}, \mathrm{p} .63)$. The land environments have been classed as mountainous or lowland, the former being represented by active volcanic chains of andesitic type. Because volcanoes are rarely preserved in the stratigraphic record, being vulnerable to erosion, we have classed all andesitic volcanics as mountains, even though their products are typically only preserved in the marine environment. Our idea is that volcanoes must have occurred nearby in such instances, probably within the area covered by the symbol on the map.

The following sections constitute a paleocontinent by paleocontinent review of evidence for orientation and paleogeography during early Silurian times.

Gondwana (includes South America, Florida, Africa, central and southern Europe, Turkey south of the Anatolian fault, the Arabian Peninsula, Iran, Afghanistan, India, Australia, East Antarctica, and possibly West Antarctica). Paleomagnetic data are few for the Silurian of Gondwana, and only one determination is available from a stable cratonic area. This is from the Mereeni Sandstone of the Amadeus Basin of Australia (McElhinny and Embleton, 1974 , p. 5, pole no. $5.1,41^{\circ} \mathrm{S}, 40^{\circ} \mathrm{E}$ ) and would put the south pole in central Africa. This is a satisfying result because it lies on the Ordovician to Devonian polar path for Gondwana (Hailwood, 1974, p. 383) and accounts very well for the lithofacies and biogeographic patterns. In this orientation the latest Ordovician-earliest Silurian (?) glacial deposits of Africa (Beuf et al, 1966) and South America (Berry and Boucot, 1972, p. 2) would be above $40^{\circ} \mathrm{S}$, and the evaporites of western Australia (Playford et al., 1975 , p. 458 ) would be between 10 and $20^{\circ} \mathrm{S}$. The Coral and Pentamerus faunas of Australia, India, and vicinity would be below $55^{\circ} \mathrm{S}$; the low diversity Clarkeia faunas of Africa and South America would be from $40^{\circ}$ to $65^{\circ} \mathrm{S}$; while south of this shelly faunas are practically lacking (see section on biogeography). There is an anomalous occurrence of the Silurian cosmopolitan fauna in Turkey (Berry and Boucot, 1972b, p. 56), but this area is north of the Anatolian fault, and we assume that this area was perhaps attached to Baltica in the Silurian.

Gondwana was by far the largest land area in Silurian times and it was flooded by marginal seas up to $2000 \mathrm{~km}$ wide during the glacio-eustatic sea level rise after the late Ordovician glacial maximum. Probably the polar regions of Gondwana remained glaciated during the Silurian, though there is no convincing evidence in the Silurian that glaciers extended into the marine area.

Subduction zones associated with Gondwana are evident in the Tasman Geosyncline of Eastern Australia (Packham, 1973) and may have continued along trend to the Ross Orogenic Zone of Antarctica, but, to date, no Silurian rocks are known in Antarctica. Volcanic rocks are also known in the Iberian 
Peninsula (Walter, 1972, table 5b), and this area, together with the other west central European areas, may have behaved as a separate microcontinent as early as the Silurian. Certainly the east-west trend of the Devonian spilites of southern Portugal and adjacent Spain (Teixeira and Thadeu, 1967, p. 190) is suggestive of some separation from Gondwana at this time while the presence of late Ordovician glacio-marine beds in Normandy might indicate affinity with Gondwana until the beginning of the Silurian.

Laurentia, Kolyma, and Barentia (includes North America, Greenland, Scotland, northwest Ireland, and Spitsbergen). Two early Silurian poles have been determined for North America (McElhinny and Opdyke, 1973, p. 3704 , Castanea $\mathrm{Fm}, 21^{\circ} \mathrm{N}, 105^{\circ} \mathrm{E}$; McElhinny, 1973, p. 285, pole no. NA 4.1, Rose Hill $\mathrm{Fm}$., $20^{\circ} \mathrm{N}, 136^{\circ} \mathrm{E}$ ). Both satisfactorily account for lithofacies distribution and the former was chosen because modern stability tests were used in its determination (both may be correct as the Castanea Fm. is slightly older than the Rose Hill Fm.). These poles indicate that Laurentia was over the equator and extended into the tropics to the north and south. Lithologically, the north tropic is indicated by evaporites in northeast Ellesmere Island (Christie, 1964, p. 23) while the south tropic is indicated by evaporites of Lake Temiskaming, on the Ontario-Quebec border (Bolton and Copeland, 1972, p. 6) and by the presence of the authigenic minerals (hematite, chamosite, phosphorite) of the Appalachian Basin (Hunter, 1970).

The most striking feature of Silurian Laurentia is the widespread limestone and dolomite deposits of Bahamian type. Berry and Boucot (1970, p. 45) have argued convincingly that much of Laurentia must have been covered by shallow seas because of the uniformity of carbonate rocks and faunas, and the lack of a clastic component in the interior region, indicating an absence of internal source regions.

Evidence of subduction is found along several segments of the margin of Laurentia. The Caledonian-Taconic border (Ziegler, 1970, 1972; McKerrow and Ziegler, 1971) was the site of andesite volcanism, and successively accreted flysch wedges from the late Ordovician through the Silurian, and this resulted in the Eocaledonian and Taconic Mountains. This mountainous tract shed sediments into the trenches on the Iapetus Ocean side and into the shallow Appalachian Basin on the margin of the Canadian Shield.

Silurian subduction and mountain building is also evident in the Franklinian Geosyncline of the Canadian Arctic. Volcanic flows are known from the north coast of Ellesmere Island (Douglas, 1970, Chart IV), and this area was evidently the source for the clastics to the south. Unlike the situation in the Appalachians, where sedimentation maintained a gradient onto the platform, a deep trough existed in the Canadian Arctic between the volcanic trend and the platform during Silurian times. The intrusive igneous rocks of northern Alaska (Churkin, 1973, p. 15) could represent the continuation of the Franklinian compressive plate boundary.

The third subduction zone associated with North America occurred along 
its western margin and remnants are to be found in the Klamath Mountains of California and in southeast Alaska (Churkin, 1974). This seems to have been of island-arc type, well separated from the margin of the carbonate platform by an area of deep-water shales (Matti et al., 1975). The original position of this island arc is uncertain because of subsequent tectonic compression, and it has been suggested that southeast Alaska may have been translated northward along strike to its present position in post-Jurassic times (Jones et al., 1972; Packer and Stone, 1974).

Finally, the Silurian relations of Kolyma and Barentia to North America are uncertain. No paleomagnetic data are available from either area, nor are Silurian rocks known from the Barents Craton. Silurian carbonates of Kolyma are consistent with its having been in its present relation to North America.

Baltica (includes northern Europe, southeast Newfoundland, Nova Scotia, and coastal areas of New Brunswick and New England). The available poles for the stable part of the Russian Platform (McElhinny, 1973, p. 292, pole nos. RP4.1, 8N,146E and RP4.2, 20N,151E) were averaged and indicate that Baltica was located in the equatorial zone. This orientation is confirmed by evaporites in the Northern Urals (Vinogradov, 1968) and places Baltica appropriately for its collision with Laurentia at the end of Silurian. A recently published pole for southern Britain (Piper, 1975) would suggest that this area was about $10^{\circ}$ south of the position shown (Fig. 2) and it is possible that southern Britain did not, in the Silurian, bear its present position relative to northern Europe. The Silurian location of the Avalon platform (southeastern section of New England and the Maritime Provinces of Canada) is unknown, though its collision with North America during the Acadian Orogeny would suggest that it was not far away.

Subduction associated with Baltica is known from southern Britain and was apparently in a waning phase (Dewey, 1969, p. 126). By contrast, early Silurian basalts along the Urals (Vinogradov, 1968) seem to be the precursors of an important andesitic chain during the Devonian and Carboniferous. These changes may have been in response to a world-wide change in plate regime brought about by the closure of the Iapetus Ocean.

Baltica was flooded to a certain extent by shallow carbonate seas in the Baltic States (Kaljo, 1972) and in the northern Urals (Vinogradov, 1968). The intervening area, the "Balto-Sarmatian continent", was probably a lowland region. The coast of the land mass is indicated by community patterns in Estonia (Kaljo, 1972).

Siberia and Kara (includes Siberia, Mongolia, and parts of North China). The single available Lower Silurian pole (McElhinny, 1973, p. 214, pole no. SB $4.1,2 \mathrm{~N}, 98 \mathrm{E}$ ) was used to orient Siberia. McElhinny (p. 215) considered this pole to be less reliable than earlier and later Paleozoic poles, but more recent data (Khramov et al., 1974) indicate that this pole is close to Lower 
Devonian poles and so the alternative Lower Silurian path of McElhinany $(1973$, p. 215) would seem to be preferred. Silurian Siberia would therefore have been "upside down" with respect to its present position; Mongolia would have been on the north side, between $40^{\circ}$ and $50^{\circ} \mathrm{N}$, and this would account for the presence of low diversity faunas in this region (see section on biogeography). Other regions of the Siberian platform contain faunas very similar to North America during the Ordovician and Silurian (Bergström, 1973; Cocks and McKerrow, 1973; Jaanuson, 1973; Kaljo and Klaaman, 1973; Whittington and Hughes, 1972; Williams, A., 1973), and so we have placed Siberia close to North America in our reconstruction. The location of the small Kara Plate in the Silurian is unknown and it has been left out of our reconstruction.

Paleozoic Siberia was dominated by the Angaran Mountains, the result of successively accreted geosynclinal belts from Lake Baikal to Mongolia (see Zonenshain et al., 1971, p. 230). Adjacent to this, Silurian geosynclinal deposits occur along the South Mongolian Geosyncline (Amantov, 1970, p. 26). Although this geosyncline did not terminate until the Carboniferous, we show the small microcontinent of South Gobi in its present position relative to Siberia and feel that it must be in this general vicinity because of the presence of the distinctive Tuvaella fauna (see section on biogeography).

The Angaran Mountains shed clastic debris onto the stable part of Siberia and these deposits grade into carbonates in central Siberia (Vinogradov, 1968). Graptolitic deposits in the Taymyr region suggest the margin of the shelf in this area but the other margins are obscured by the overthrust Verkhoyansk Mountains and by the deeply subsided West Siberian Lowlands.

Kazakhstania (includes areas of the U.S.S.R. and China east of the Urals, southwest of the Altai and north of the Pamirs). Unfortunately, no Silurian paleomagnetic data are available from this area, although data for the Middle Devonian through Lower Triassic exist (McElhinny, 1973, p. 297-299, pole nos. SB 5.7, 5.12, 5.15, 6.1,6.11, 6.12, and 8.6). These together with lithofacies data are shown on Table I. In the Upper Paleozoic, most of the paleomagnetic determinations are consistent with estimates of paleolatitude determined from lithofacies data (the exceptions are pole numbers SB 5.12 and SB 6.1 both from the same area, which are inconsistent with both lithofacies data and other paleomagnetic data). The Upper Paleozoic data indicate a northward migration of Kazakhstania from about $10^{\circ} \mathrm{N}$ to $40^{\circ} \mathrm{N}$. The Ordovician and Silurian reefs, carbonates and thick clastics (over $1000 \mathrm{~m}$ per unit geologic series) are suggestive of an equatorial regime, while Eo-Cambrian tillites indicate cold climates. Therefore a constant northward Paleozoic migration of Kazakhstania would seem to be the simplest interpretation of the available data, and we show Kazakhstania over the equator in our reconstruction in an orientation consistent with later Paleozoic paleomagnetic information.

Kazakhstania seems to have been the Paleozoic equivalent of southeast 


\section{TABLE I}

Climatic belts and their latitudes

\begin{tabular}{|c|c|c|c|c|c|c|c|c|}
\hline \multirow[t]{3}{*}{ Time unit } & \multicolumn{3}{|c|}{ South } & & & & \multicolumn{2}{|r|}{ North } \\
\hline & $90^{\circ}$ & $60^{\circ}$ & $30^{\circ}$ & $10^{n}$ & $10^{\circ}$ & $30^{\circ}$ & $60^{\circ 2}$ & $90^{\prime \prime}$ \\
\hline & & $\begin{array}{l}\text { cold- } \\
\text { dry }\end{array}$ & $\begin{array}{l}\text { cool- } \\
\text { wet }\end{array}$ & $\begin{array}{l}\text { warm- } \\
\text { dry }\end{array}$ & $\begin{array}{l}\text { hot- } \\
\text { wet }\end{array}$ & $\begin{array}{l}\text { warm- } \\
\text { dry }\end{array}$ & $\begin{array}{l}\text { cool- } \\
\text { wet }\end{array}$ & $\begin{array}{l}\text { cold- } \\
\text { dry }\end{array}$ \\
\hline
\end{tabular}

Triassic

Permian Up

Lr.

$1 \mathrm{e} \quad \mathrm{c}$

Carboniferous Up.

Lr.

L. C $\quad$ C P

$\mathrm{LE} \mathrm{Z} \quad \mathrm{C} \mathrm{P}$

\begin{tabular}{lll} 
Devonian & Up. & c \\
& Md. & c r \\
\multirow{5}{*}{ Silurian } & Lr. & L C R \\
& Up. & L C R \\
\multirow{3}{*}{ Ordovician } & Lr. & L C R \\
& Up. & \\
& Md. & L C R \\
& Lr. & L C R
\end{tabular}

$\begin{array}{llll}\text { Cambrian } & \text { Up. } & \mathrm{L} & \mathrm{c} \\ & \text { Md. } & 1 \mathrm{z} & \mathrm{C} \\ & \text { Lr. } & \mathrm{L} & \end{array}$

\begin{tabular}{|c|c|c|c|c|c|c|c|}
\hline Eo-Cambrian & & $\mathrm{T} \mathrm{C}$ & 2 & & & & \\
\hline \multicolumn{8}{|l|}{ Lithofacies } \\
\hline Carbonates & & & $L$ & $\mathrm{~L}$ & $\mathrm{~L}$ & & \\
\hline Reefs & & & $\mathrm{R}$ & $\mathrm{R}$ & $\mathrm{R}$ & & \\
\hline Evaporites & & & $\mathrm{E}$ & & $\mathrm{E}$ & & \\
\hline Authigenic mins. & & & 7 & & $\mathrm{Z}$ & & \\
\hline Thick clastics & & $\mathrm{C}$ & & $\mathrm{C}$ & & $\mathrm{C}$ & \\
\hline Coal or peat & & $\mathrm{p}$ & & $\mathbf{P}$ & & $\mathrm{P}$ & \\
\hline Tillite & $\mathrm{T}$ & $\mathrm{T}$ & & & & $\mathrm{T}$ & $\mathrm{T}$ \\
\hline
\end{tabular}

Paleo-latitudinal track of Kazakhstania. The predicted latitudinal occurrence of lithofacies is shown at the bottom of the table (Emery, 1969; Briden, 1968). The Kazakhstania lithofacies information (Vinogradov, 1968-9) is indicated by letters (capital letters for widespread deposits, and small letters for local occurrences). The paleomagnetic data (McElhinny, 1973) is indicated by horizontal bars (astersks indicate determinations that are incunsistent with other data). 
Asia. Andesitic volcanism is evident from the late Precambrian to the Permian (Vinogradov, 1968, 1969) and zones of volcanism seem to migrate radially to cover areas of successively accreted oceanic deposits. A Precambrian core of 1.4 billion years is known in the Kokchetav Massif (Rozen et al., 1972). By Silurian times Kazakhstania seems to have been horse-shoe shaped with the Balkash Sea in the center (Vinogradov, 1968).

North China, South China, Tibetia, and Malaysia. The position of these microcontinents in the Paleozoic world is very uncertain and the number of speculations on the subject would seem to be inversely proportional to the availability of relevant data (see Griffiths and Burrett, 1973 for a review). In the general absence of paleomagnetic data, biogeographic arguments have been employed to try to relate these areas to better known parts of the world. However, little attention has been paid to facies in assessing faunal patterns; thus Burrett (1974, p. 185) described as "slightly embarrassing" the occurrence of an Australian Cambrian trilobite from South China adjacent to distinctly different faunas of the Yangtzi Paraplatform. This trilobite came from a geosynclinal facies on Hainan Island while other South Chinese forms are from the shallow platform. Because of such ambiguities, we put reliance on climatic, rather than biogeographic arguments in the following discussion.

A Silurian pole for North China has been published (Khramov et al., 1974 , p. 219 , pole no. S1, 39S,205E) and would place this area in the tropics. Silurian deposits are rare in North China, but Ordovician evaporites do occur (Li, 1956, p. 26) and though somewhat temporally displaced would tend to confirm the pole of Khramov. No polar path has been determined for North China, so the Silurian pole is unconfirmed, and could, of course, represent a north or south pole. We assume that it is the former, and that North China was over the south tropic in the Silurian. It seems to us that the simplest migration path of North China would be northward to the time of its collision with Siberia in the Permian. We point out that the Carboniferous coals of North and South China are the province of the thermophilic Cathaysian floras (Meynen, 1969), and assume that these areas were over the equator at this time. The position of Tibetia is very uncertain and we assume it was close to North China in our reconstruction because of the collision of the two in the late Devonian or early Carboniferous (Huang, 1960, p. 509).

South China must have been much further south than normally shown in late Paleozoic reconstructions because of the Cathaysian Floral Province. We assume that it was further south still in the Silurian, and not too far from North America, to account for the presence of elements of the tropical fauna (see section on biogeography). We include Indo-China with South China, but show it northwest relative to China because of the truncation of the aforementioned geosynclinal deposits of Hainan Island. We assume that the Paleozoic deposits of Japan represent the continuation of this same geosyncline.

South China has a good Silurian stratigraphic record (Lee, 1939; Li, 1956; 
Roger, 1963). Coarse clastics in the south grade north into fine clastics and some carbonates, indicating land to the south.

Malaysia has been a volcanic arc during most of its Phanerozoic history, though its polarity in the Paleozoic was apparently the opposite of the present situation (Hutchison, 1973). Sediments indicate that Malaysia was against a continent in the Cambrian and we assume that it was a somewhat detached arc by Silurian times related to the Tasman Orogenic Zone of eastern Australia.

\section{EARLY SILURIAN PALEOCLIMATOLOGY}

The following discussion was generated using modern climatologic concepts (Barry and Chorley, 1970) and the assumption that the Silurian atmospheric circulation operated on the same principles as the present. Atmospheric pressure distribution and circulation at the Earth's surface is inferred for the early Silurian in Figs. 3 and 4 . Wind directions are drawn approximately parallel to the isobars, the flow about a low-pressure system being cyclonic (counter-clockwise in the northern hemisphere and clockwise in the southern hemisphere). Slight cross-isobaric flow is shown directed towards lower pressures.

Since the northern hemisphere was predominantly ocean, a zonally uniform climate would be expected. The wind pattern would have been distinguished by polar easterlies at high latitudes, prevailing westerlies at mid latitudes, and northeast trades in the tropics. In the southern hemisphere, given the Gondwanian Continent centered at the pole, climate would have been influenced to a greater degree by the distribution of land and water masses. The resulting circulation pattern was certainly more cellular and complex than in the northern hemisphere.

\section{Atmospheric circulation for northern hemisphere summer}

During the northern hemisphere summer (Fig. 3), high pressure would have covered the polar ocean while a broad belt of low pressure encircled the globe at about 60 degrees north latitude. The low pressure was probably intensified where it passed to the north of Siberia. Above the subtropical oceans distinct high-pressure cells would have formed, similar to the presentday Bermuda high over the subtropical North Atlantic.

A second band of low pressure would be expected near the thermal equator (region of most intense solar heating), migrating with the thermal maximum throughout the season. This would form the Silurian intertropical convergence zone (ITCZ), where the northeast and southeast trade winds converged, and where uplifting and cooling of the tropical air would cause extensive cloudiness and precipitation. The ITCZ was probably within a few degrees of the equator, but it may have extended as far as 10-15 degrees north in areas where the intense summer heating was concentrated by land. This was most 

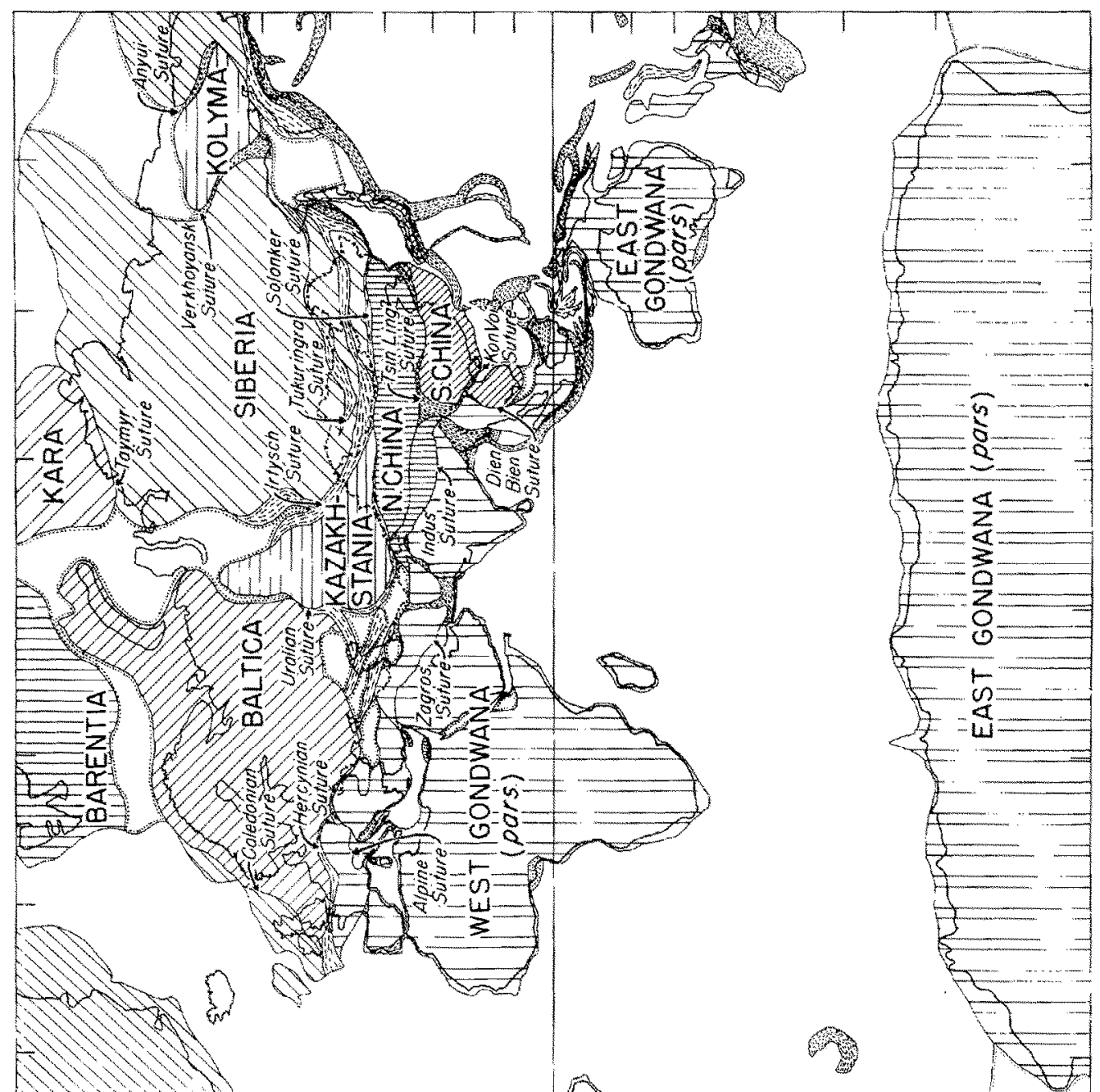

送
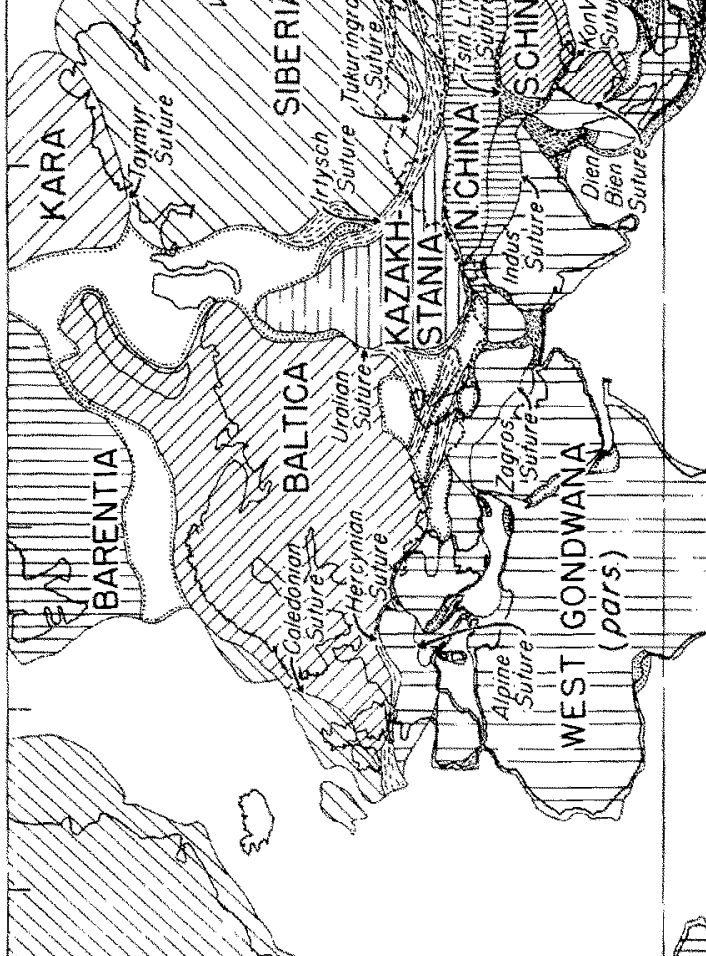

e

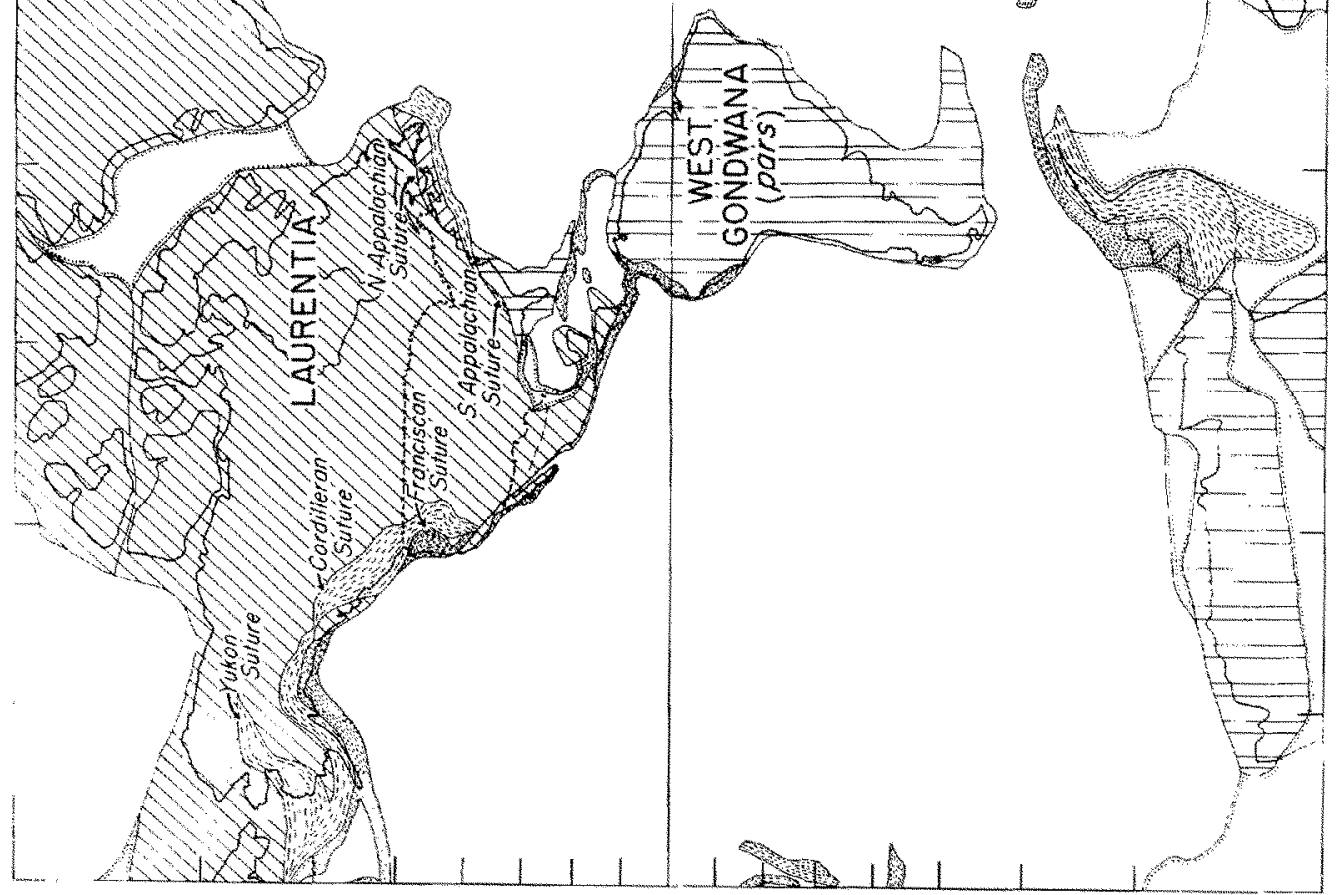



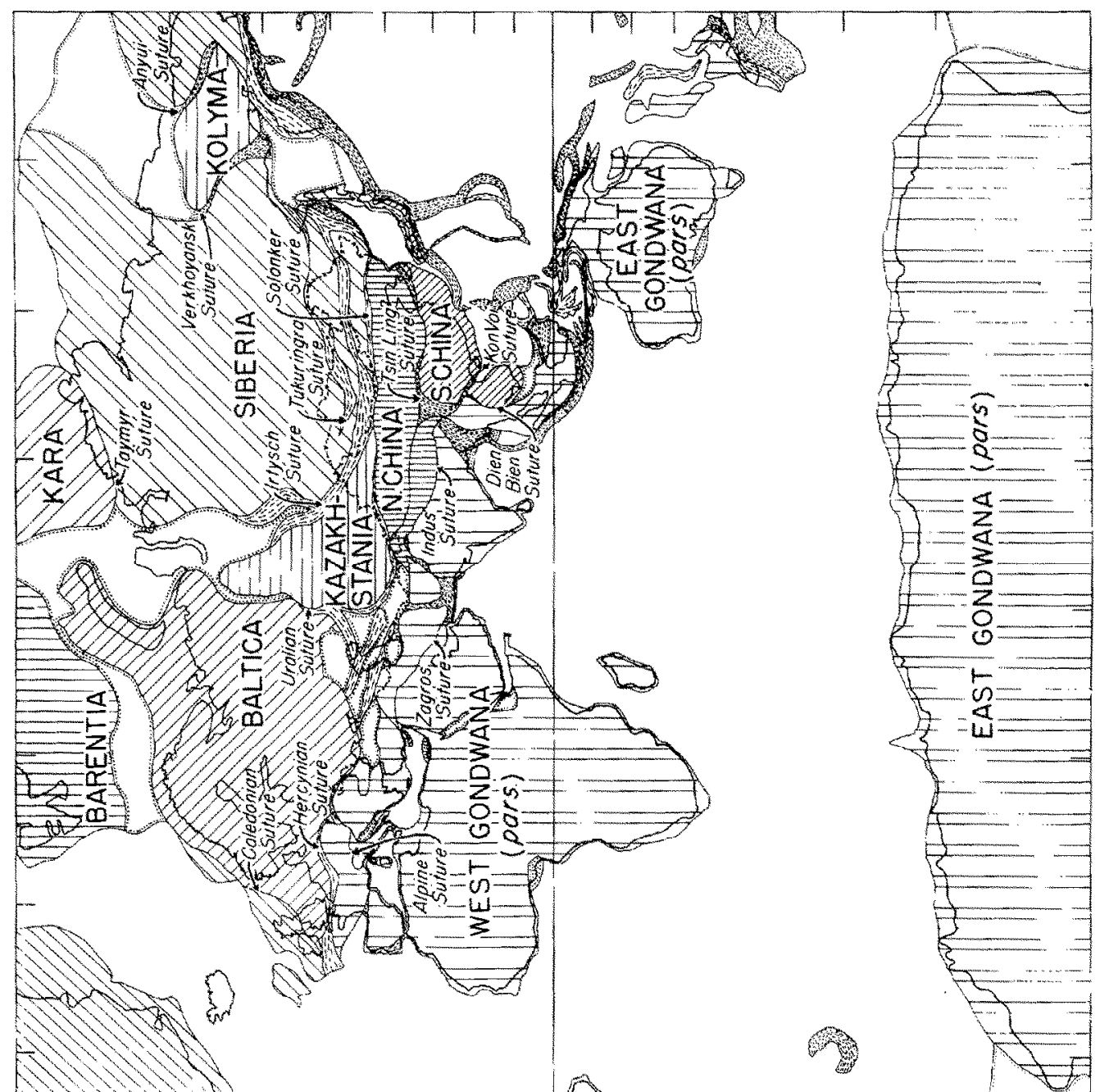

送
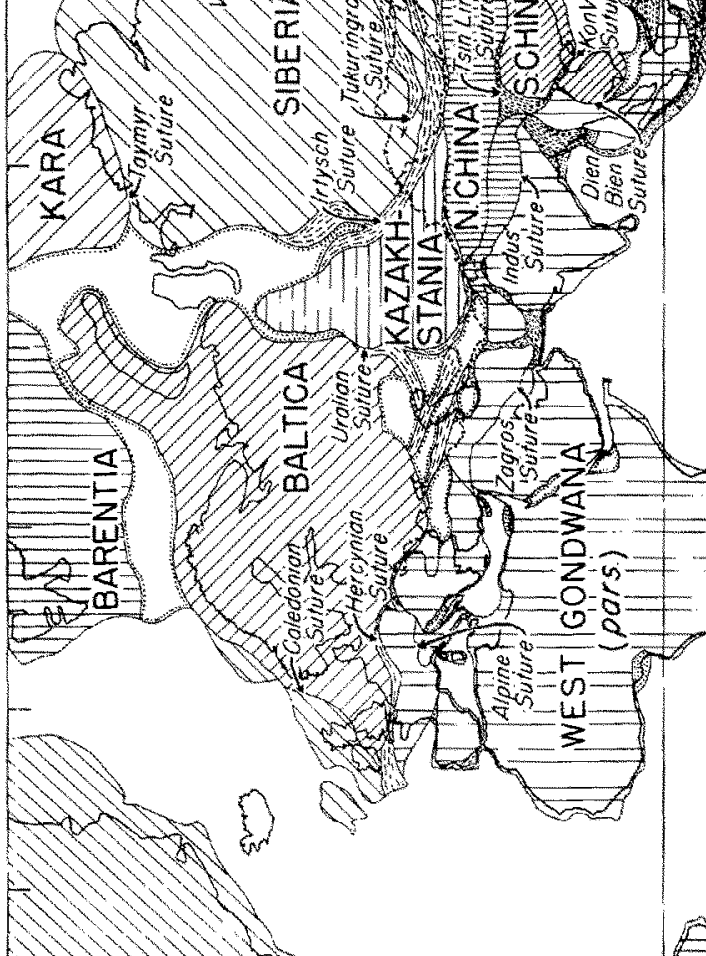

e

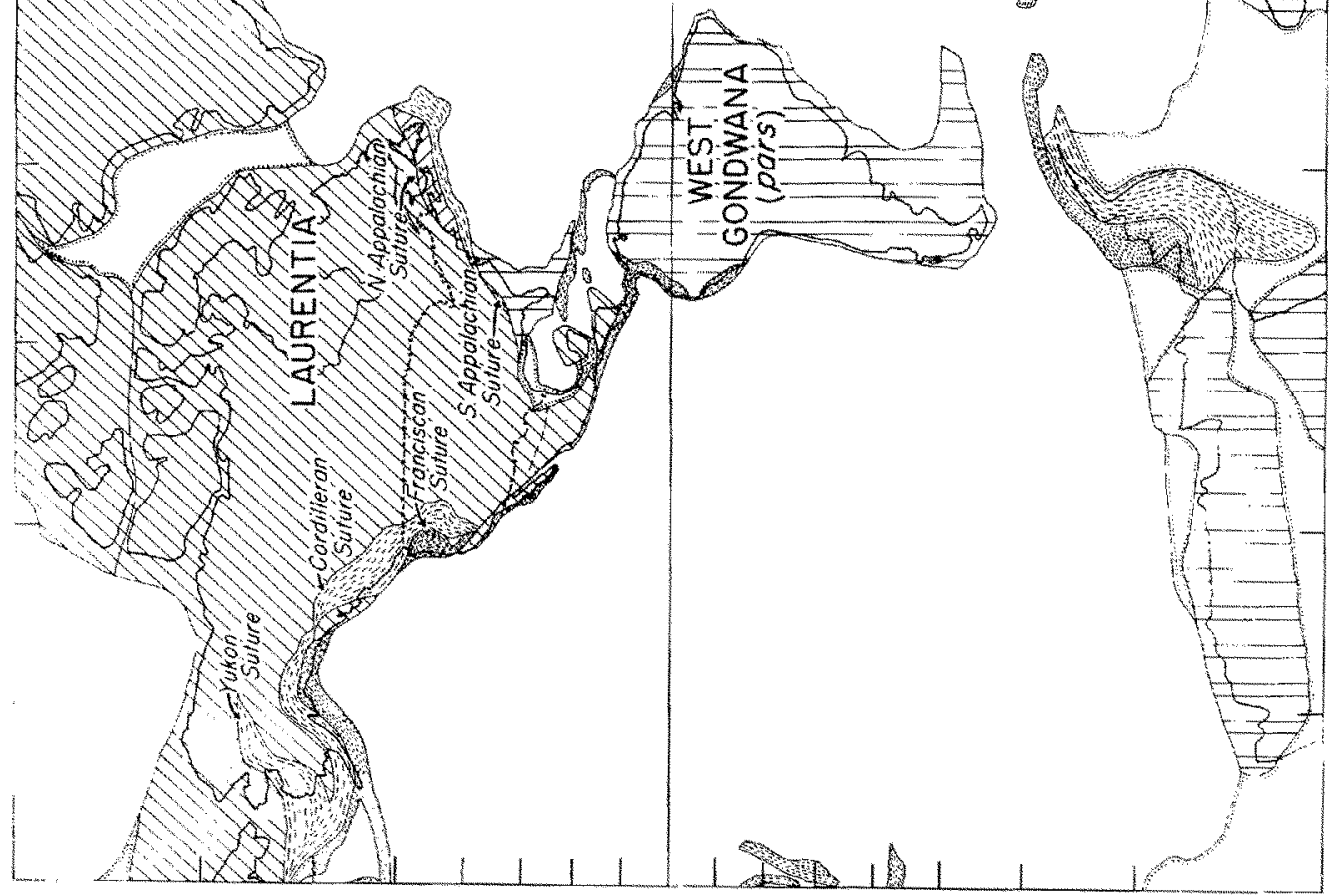




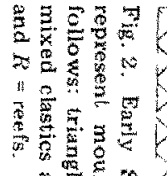

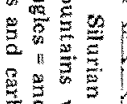

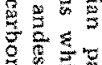

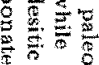

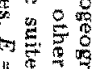

昰总

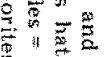

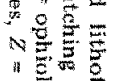

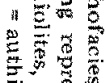

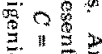

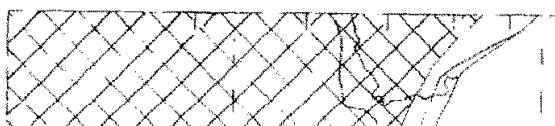

b

然等

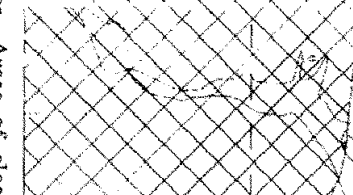

" 8 क

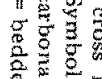

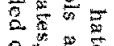

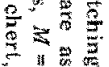
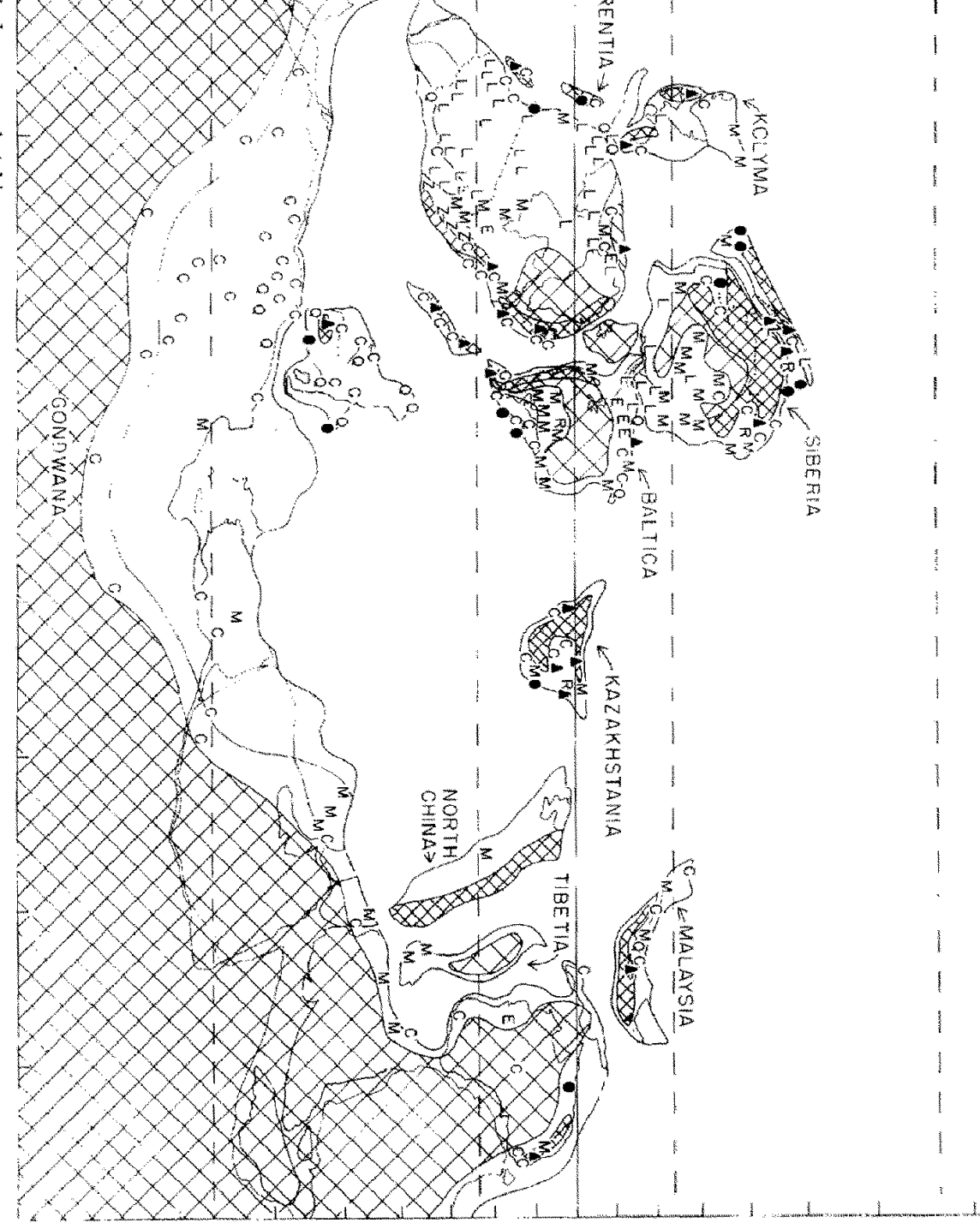


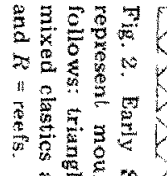

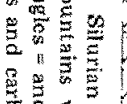

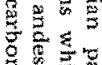

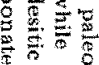

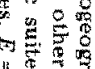

昰总

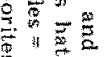

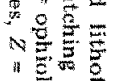

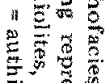

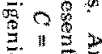

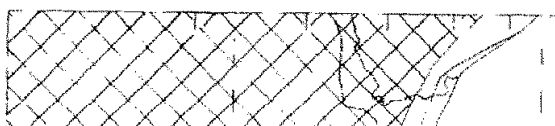

b

然等

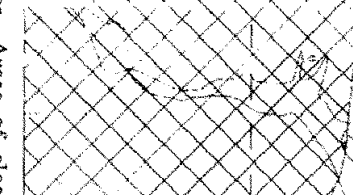

" 8 क

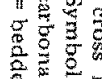

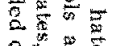

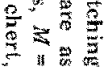
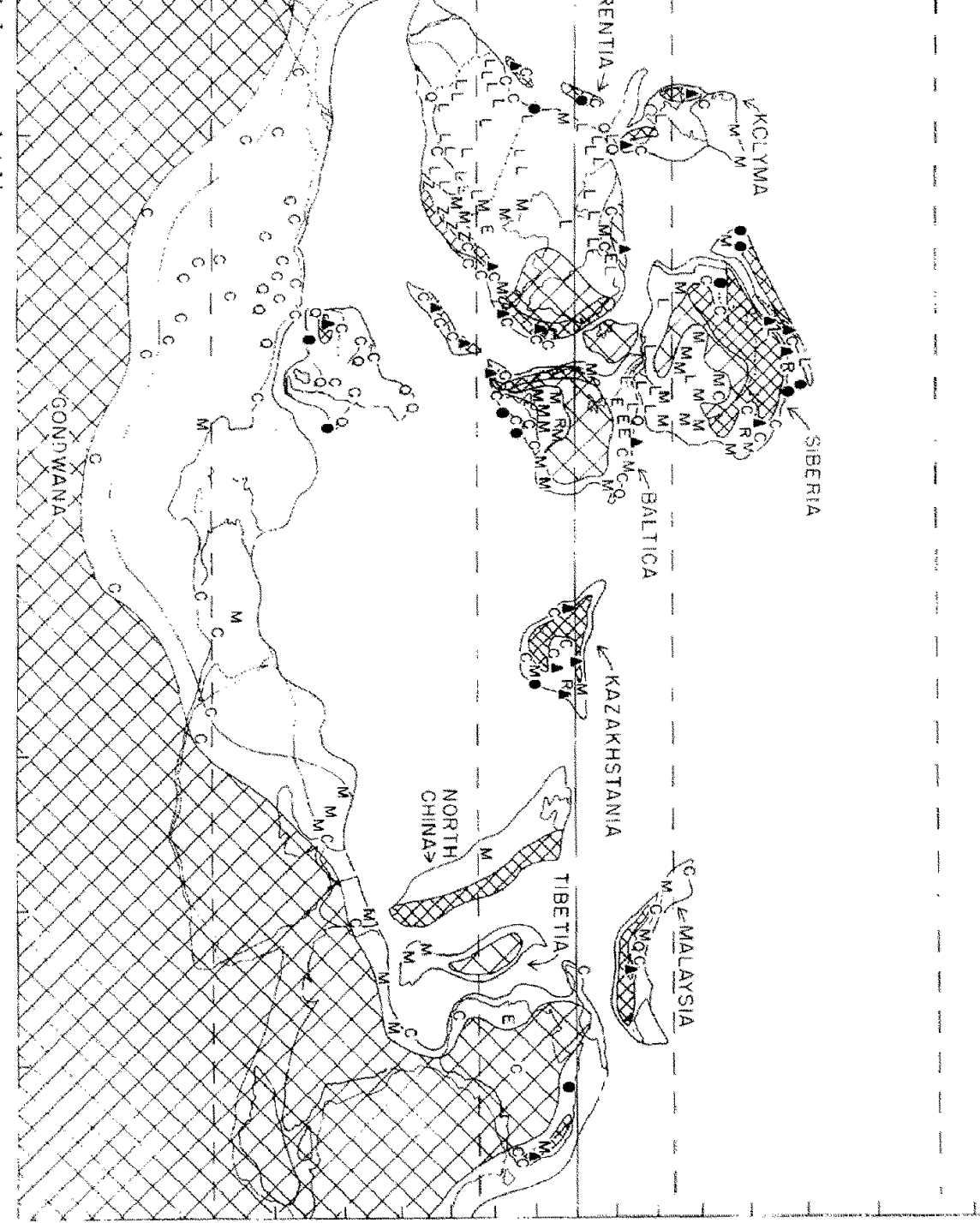


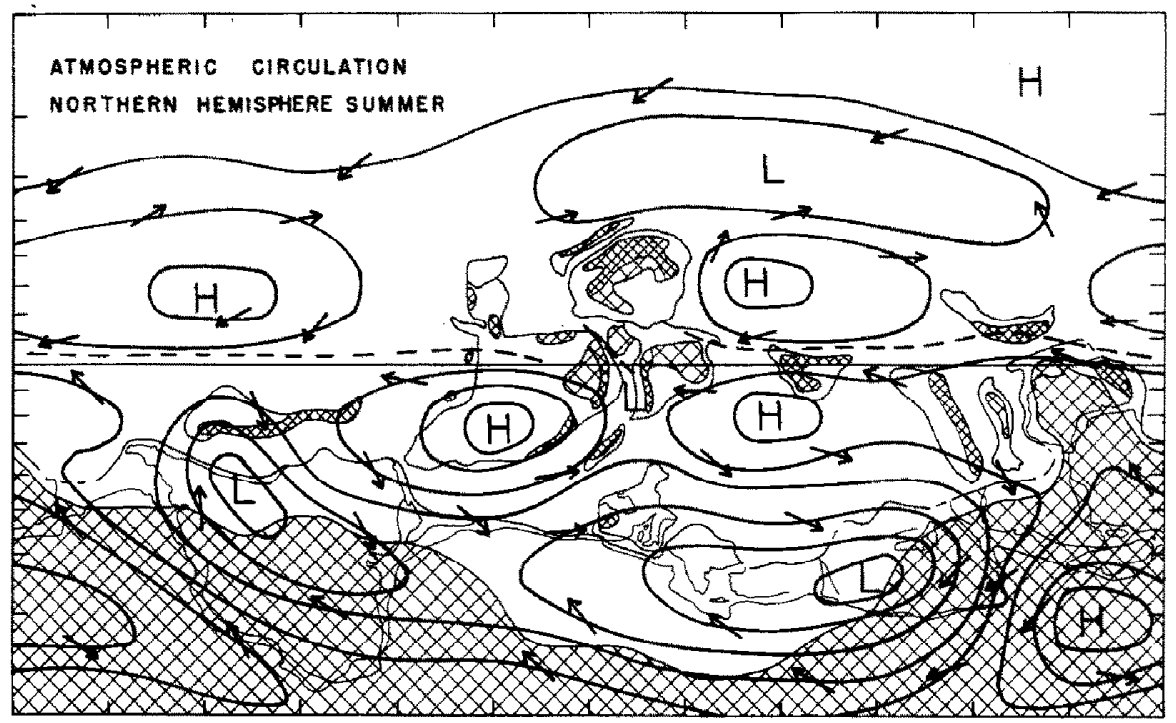

Fig. 3. Atmospheric pressure distribution and circulation for northern hemisphere summer in the early Silurian. Solid lines are surface isobars, dashed line is the intertropical convergence zone, and arrows indicate surface wind direction. The relative strength of a low-pressure center $(L)$ or high-pressure center $(H)$ is indicated by the number of closed contours around the cell.

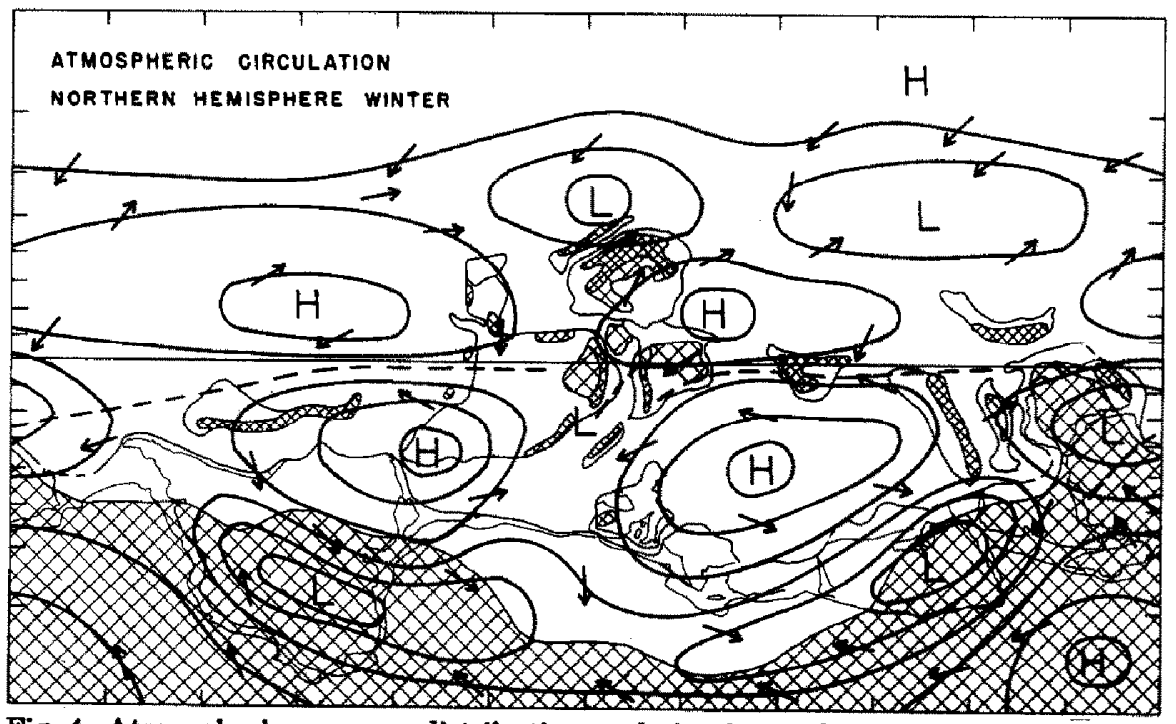

Fig. 4. Atmospheric pressure distribution and circulation for northern hemisphere winter in the early Silurian. Markings are the same as in Fig. 3. 
likely true along the eastern margins of tropical continents, where anticyclonic circulation around the subtropical highs drew warm, moist air northwestward from equatorial ocean regions. Conversely, the ITCZ may have weakened or disappeared completely along western margins of the continents, which were influenced by cooler, subsiding air flowing southward around the easternmost sector of subtropical highs.

The corresponding southern hemispheric circulation would have been considerably more vigorous than its northern hemisphere counterpart for two reasons: (1) a greater abundance of land results in more intense thermal and moisture gradients within the atmosphere; and (2) the winter hemisphere has a greater latitudinal insolation gradient at the top of the atmosphere than the summer hemisphere.

Subtropical highs of the southern hemisphere probably expanded over the continental land masses, where anticyclonic patterns were thermally reinforced by winter cooling of the land. This would have occurred above the Australian-Antarctic portion of Gondwanaland, where a north-south oriented pressure ridge would merge the subtropical high pressure into a cold, massive cell located at higher latitudes above the continental interior. Comparatively low pressures would have covered the broad Gondwanian shelf, with more intense cells (similar to the present-day Icelandic and Aleutian lows) located just of the east and west coasts of Gondwanaland.

\section{Atmospheric circulation for northern hemisphere winter}

With reversal of the seasons (Fig. 4), circulation in the northern (winter) hemisphere was probably strengthened due to the increased pole-to-equator insolation gradient. However, circulation in the southern (summer) hemisphere would have been maintained at approximately the same level while the effects of continentality neutralized the changes in the receipt of solar radiation. The pressure and circulation patterns would shift some to the south in both hemispheres. This is illustrated in the position of the ITCZ, which moves from the northern into the southern hemisphere following the thermal equator.

A high-pressure belt is depicted covering the north polar ocean, while a low-pressure cell is shown off the northern coast of Siberia. Subtropical highs of the northern hemisphere probably expanded onto the continents but weakened slightly over the oceans, while the reverse situation occurred for subtropical highs of the southern hemisphere.

The most striking seasonal change would be expected over AustralianAntarctic Gondwanaland, where summer heating of the land would replace the high pressure of winter with a thermally induced low-pressure center. This circulation would have drawn the ITCZ far poleward into the Antarctic interior, much as the morisoons of today draw the ITCZ over the Indian subcontinent during northern isemisphere summer. The continental high- 
pressure cell would therefore be displaced poleward and significantly weakened.

\section{Oceanic circulation}

The major oceanic surface currents are established in response to the lowlevel atmospheric circulation (Neumann and Pierson, 1966). Current flow is generally westward beneath polar easterlies and easterly trades but eastward in the region of prevailing westerlies. Where the oceans are interrupted by north-south land barriers, the currents are deflected longshore to form anticyclonic gyres at low latitudes and cyclonic gyres at higher latitudes. For these closed circulation systems, the Earth's rotation constrains the flow in such a manner that the strongest currents develop on the western sides of the oceans (Stommel, 1948). Examples of intense western boundary currents are the warm Gulf Stream in the Atlantic and Kuroshio in the Pacific and the cold Oyashio Current flowing southward from the Bering Sea towards Japan.

The principles outlined above were applied to the Silurian geography and atmospheric circulation of Figs. 3 and 4 to construct the wind-driven ocean circulation shown in Fig. 5.

A north polar circum-global current, driven by the polar easterlies, would have flowed westward at high northern latitudes. In response to the prevailing westerlies, eastward flow would dominate the mid latitudes with maximum strength at about 45 degrees. Anticyclonic gyres probably circulated around the northern hemisphere subtropical oceans. Western boundary currents

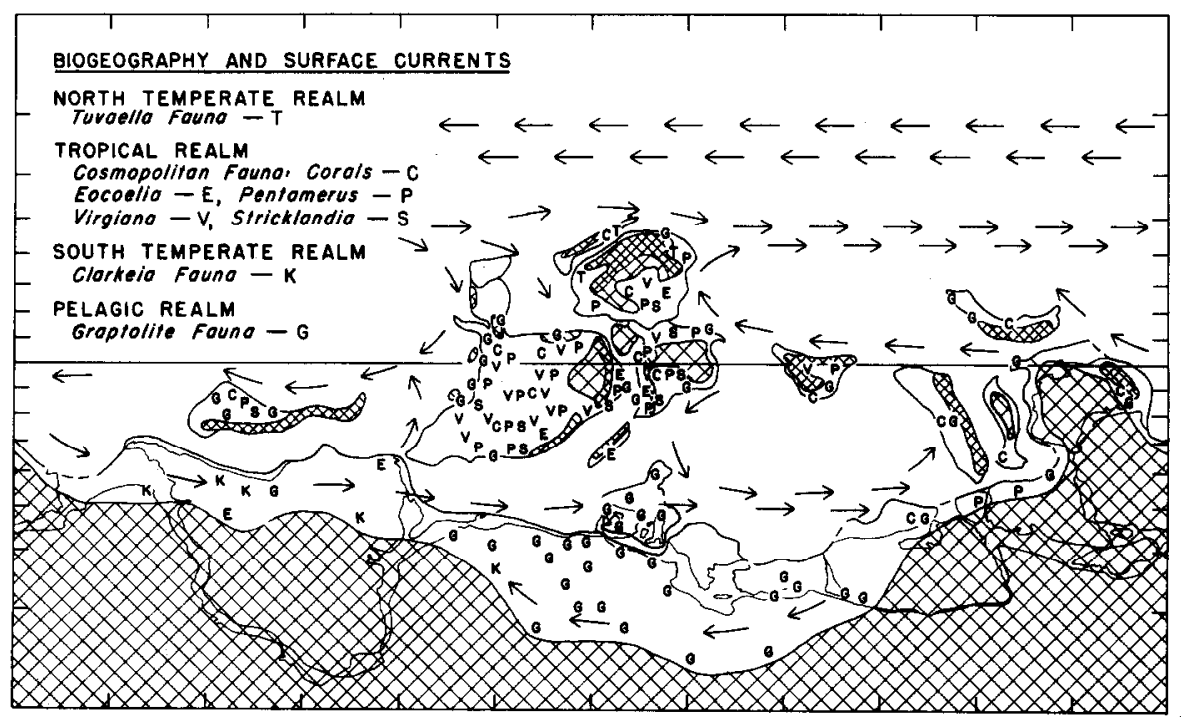

Fig. 5. Biogeography and wind-driven surface currents (annual mean) in the early Silurian. 
would have been only weak to moderate in strength, owing to the lack of distinct north-south land barriers. This is analogous to the situation in the subtropical South Pacific today, where the East Australian Current is a relatively weak western boundary flow.

Oceanic circulation of the southern hemisphere would have consisted of three current systems. These include two anticyclonic gyres in the subtropical oceans, and a cyclonic system at higher latitudes on the Gondwanian shelf. Well-defined ocean boundaries would have permitted the development of a strong western boundary current in each gyre.

\section{Climatology of the continents}

Eastward-travelling low-pressure systems would have brought moderate amounts of rainfall to the northern coast of Siberia, especially during the winter season, when storms were well developed. Heaviest rainfall probably occurred on the northern slopes of coastal mountains bordering Siberia. Dry regions would be expected at about 25-30 degrees north latitude, particularly on the western portion of the land areas, as a result of subtropical high pressure.

Southerly winds around the western sector of a subtropical high would have brought moisture-laden tropical air and precipitation to the eastern portions of Baltica and Siberia, especially during the summer. However, most of the moisture probably rained out over central Baltica (note position of ITCZ in Fig. 3), resulting in little if any rain on the north coast of Baltica. Moisture could have been regained over the Siberian shelf and rained out on the southern slopes of the interior mountains.

The ITCZ probably brought rain to the eastern slopes of the mountains bordering equatorial Laurentia, while a rain-shadow effect caused drier conditions on the western slopes. Rainfall would have picked up again where the ITCZ was regenerated on the equatorial Laurentian shelf. The southeast coast of Baltica would have received rain during the southern hemisphere summer from the ITCZ, and also enjoyed a moist climate during the winter owing to the nearby warm ocean current. Subtropical high pressure would cause desert conditions near 25-30 degrees south latitude over the Laurentian shelf and the Australian shelf off the west coast of Gondwanaland.

Much of the Gondwanian shelf probably received moderate rainfall throughout the year with the passage of low-pressure systems eastward from Argentina toward Arabia. Heavy rain would have occurred along the Argentine coast and the Arabian-Indian coast. During the summer, monsoon-like rains would have occurred on the island-arc mountains off Australia and in Antarctic Gondwanaland. Polar regions of Gondwanaland are expected to have been extremely dry due to isolation from moisture supplies. Intense cold would have prevented the melting of snow, creating a potential for glaciation as in the present-day Antarctica. 


\section{EARLY SILURIAN BIOGEOGRAPHY}

All authors on Silurian biogeography agree that the Silurian was a period of exceptional cosmopolitanism (Berry, 1973; Boucot and Johnson, 1973; Cocks and McKerrow, 1973; Kaljo and Klaaman, 1973). Boucot and Johnson recognized three biogeographic subdivisions: the Cosmopolitan Province, the Malvinokaffric Province, and The Mongolo-Okhotsk Province. We follow this basic subdivision, and our reconstruction suggests that the Cosmopolitan Province is tropical and equatorial while the latter two represent the south and north temperate zones, respectively. We also recognize the pelagic realm, represented primarily by the oceanic graptolites. The distribution of key elements of these provinces is shown in Fig. 5.

Tropical Realm. The most distinctive elements of the Cosmopolitan Province are the rhynochonellid brachiopod Eocoelia, and the pentameracean brachiopods Pentamerus (including P. borealis, P. oblongus, and Pentameroides), Virgiana, and Stricklandia (including Costistricklandia). Corals have also been plotted because their distribution is indicative of water temperature.

Pentamerus is the most universally distributed element of the Cosmopolitan Province and occurs in the low-latitude portions of all Silurian continents. It occurs equally abundantly in Bahamian and geosynclinal shelf environments, as does Stricklandia. Virgiana is more restricted to the Bahamian environments, and may be more latitudinally confined. By contrast, Eocoelia seems to be limited to clastic environments, and its distribution is limited to a relatively narrow belt from South America, along the Iapetus Ocean, to Siberia.

The corals suffered a great reduction in numbers and genera at the end of the Ordovician (Kaljo and Klaaman, 1973, p. 40) which could be related to severe climatic conditions associated with the late Ordovician glacial advances in Gondwana. In the Silurian coral reefs did not become abundant until the Upper Llandovery when there was a "great burst of Silurian coral vigour, numerous new families, genera and species entering" (Hill, 1958, p. 165).

Temperate Realms. The south temperate Malvinokaffric Province represented by the Clarkeia Fauna (Cocks, 1972) is known from South America and adjacent parts of south and north Africa. This fauna is of low diversity and has been interpreted as a cold water fauna. The north temperate Mongolo-Okhotsk Tuvaella fauna (Boucot and Johnson, 1973) is restricted to Mongolia and adjacent parts of Siberia and also seems to be of low diversity.

Pelagic Realm. Graptolite rich faunas occur along the margins of the shallow platform regions and are especially diverse in deposits interpreted to be oceanic in nature. Like the corals, the Silurian graptolites evolved from the remnants of a late Ordovician extinction (Berry, 1973, p. 86). 


\section{GENERAL CONCLUSIONS}

(1) Climate and latitude. Silurian lithofacies patterns associated with continents whose orientations are well established by paleomagnetic evidence suggest that during the Silurian, the Earth's general atmospheric and oceanic circulation was essentially the same as today. However, climatic belts were probably more nearly parallel with latitude in the Silurian due to the relative absence of land areas in low latitudes.

(2) Climate and continental accretion. Today, zones of flysch accretion along present compressive plate boundaries are best developed in the equatorial and temperate belts, due to rainfall sufficient to erode and transport sediments from the mountains to the adjacent trenches. In the Silurian this process is seen in Mongolia which was north temperate, and in Scotland, Kazakhstania, and Australia which were all evidently equatorial.

(3) Continental accretion and sea level. Lateral accretion of continents by their eroded products must reduce, to some extent, the widths of ocean basins and thereby bring about a long term rise in sea level. The reverse process would be expected during the periods of continental collision when one plate may partially override another. Periods, like the Silurian, when continents were largely flooded, seem to follow long intervals when no collisions occurred, while the opposite is true of periods like the Devonian, Permo-Triassic and Tertiary.

(4) Glaciation and sea level. Glacio-eustatic changes punctuate long term sea-level changes and at the end of the Ordovician were responsible for a withdrawal of the sea from all platform areas. This had faunal, as well as stratigraphic effects, and brought about widespread extinctions.

(5) Sea level and biogeography. Widespread shallow seas facilitate communication of marine organisms and result in a lack of provinciality, except in a strictly latitudinal sense.

\section{ACKNOWLEDGEMENTS}

This work has been supported by a grant from the Shell Development Company, and we would like to express our appreciation to members of that company, in particular A.W. Bally, T.D. Cook, P.T. Lucas, and S. Snelson, for sharing their compilations, translations, and general knowledge of world geology. We are also indebted to our Chicago colleagues, C.A.F. Smith, W.C. Parker, T.J.M. Schopf and E.H. Gierlowski for their help in the final stages of the manuscript preparation. A portion of this work was carried out while one of the authors (Hansen) was a visitor at the National Center for Atmospheric Research (which is sponsored by the National Science Foundation) in Boulder, Colorado.

\section{AUTHORSHIP RESPONSIBILITIES}

In this paper, Kelly, Scotese and Ziegler assembled the information on sutures; Johnson and Ziegler collected the paleogeographic and biogeo- 
graphic data; Scotese prepared the computer reconstructions; Hansen drew the climatic interpretations; and Van der Voo assembled the paleomagnetic data.

\section{REFERENCES}

(Asterisk denotes papers used in the collection of paleogeographic and biogeographic data and not necessarily quoted in the text.)

Aam, K., 1975. Aeromagnetic basement complex mapping north of latitude $70^{\circ}$, Norway. Nor. Geol. Unders., 316: 351-374.

Adie, R.J., 1972. Evolution of volcanism in the Antarctic Peninsula. In: R.J. Adie (Editor), Antarctic Geology and Geophysics. Universitetsforlaget, Oslo, pp. 137-141.

Amantov, V.A., Blagonravov, V.A., Borzakovsky, Yu.A., Durante, M.V., Zonenshain, L.P., Luwsandansan, B., Matrosov, P.S., Suetenko, O.D., Fulunnova, I.B. and Khasin, R.A., 1970. Stratigraphy and tectonics of the Mongolian Peoples Republic. Acad. Nauk, Trans., vol. 1, The Joint Soviet Mongolian Scientific Research Geological Expedition. *

Amsden, T., 1960. Hunton Stratigraphy. Oklahoma Geol. Surv. Bull. 84, University of Oklahoma, Norman: 311 pp. *

Amsden, T. and Rowland, T., 1965. Silurian stratigraphy of northeastern Oklahoma. Oklahoma Geol. Surv. Bull. 105, University of Oklahoma, Norman: 174 pp. *

Anderson, T.A., 1975. Carboniferous subduction complexes in the Harz Mountains, Germany. Geol. Soc. Am. Bull., 86: 72-82.

Barry, R.G. and Chorley, R.J., 1970. Atmosphere, Weather and Climate. Holt, Rinehart and Winston, New York, N.Y.: 320 pp.

Becker, H., Forster, H. and Soffel, H., 1973. Central Iran, a former part of Gondwanaland? Palaeomagnetic evidence from Infra Cambrian rocks and iron ores of the Bafq area, central Iran. Z. Geophys., 39: 953-963.

Belyi, V.F., 1973. Okhotsk-Chukotsk fold belt and the problem of volcanic ares in northeast Asia. Am. Assoc. Pet. Geol., Mem., 19: 252-258.

Bergström, S.M., 1973. Ordovician condonts. In: A. Hallam (Editor), Atlas of Palaeobiogeography. Elsevier, Amsterdam, pp. 47-58.

Berry, W.B.N., 1973. Silurian-Early Devonian graptolites. In: A. Hallam (Editor), Atlas of Palaeobiogeography. Elsevier, Amsterdam, pp. 81-88.

Berry, W.B.N. and Boucot, A.J, 1970. Correlation of the North American Silurian rocks. Geol. Soc. Am. Spec. Pap., 102: 289 pp. *

Berry, W.B.N. and Boucot, A.J., 1972a. Correlation of the South American Silurian rocks. Geol. Soc. Am. Spec. Pap., 133: 59 pp. *

Berry, W.B.N. and Boucot, A.J., 1972b. Correlation of the Southeast Asian and Near Eastern Silurian rocks. Geol. Soc. Am. Spec. Pap., 137:65 pp. *

Berry, W.B.N. and Boucot, A.J., 1972c. Silurian graptolite depth zonation, 24 th Int. Geol. Congr. Sect. 7, Paleontology, pp. 59-65.

Berry, W.B.N, and Boucot, A.J., 1973. Correlation of the African Silurian rocks. Geol. Soc. Am. Spec. Pap., 147:83 pp. *

Beuf, S., Biju-Duval, B., Srevaux, J. and Kulbicki, G., 1966. Ampleur des glaciations Siluriennes au Sahara: leurs influences et leurs conséquences sur la sedimentation. Rev. Inst. Fr. Pet., pp. 363-381.

Bobylev, V.V. and Solov'yev, V.O., 1971. The Daubikhe, Alchan, and Kukan Basins and their place in the tectonic structure of the southern part of the Soviet Far East. Geotectonics, $6: 395-400$.

Bugdonov, N.A., 1973. Tectonic development of trenches in the Western Pacific. In: P.J. 
Coleman (Editor), The Western Pacific; island arcs, marginal seas, geochemistry. Crane and Russak, New York, pp. 327-333.

Bolton, T.E., 1957. Silurian stratigraphy and paleontology of the Niagaran Escarpment in Ontario. Geol. Surv. Can, Mem., 289:145 pp. *

Bolton, T.E. and Copeland, M.J., 1972. Paleozoie formations and Silurian biostratigraphy, Lake Timiskaming Region, Ontario and Quebec. Geol. Surv. Can., Pap., 7215: 49 pp. *

Borzakovskiy, Yu.A. and Suyetenko, O.D., 1970. Some of the late Paleozoic geosynclinal troughs of central and east Asia. Geolectonics, 5: 287-294.

Bott, M.P.H. and Watts, A.B., 1971. Deep structure of the continental margin adjacent to the British Isles. In: F.M. Delaney (Editor), The Geology of the East Atlantic Continental Margin, 2. Europe. Inst. Geol. Sei., Rept., 70/14:89-110.

Boucot, A.J. and Johnson, J.G., 1973. Silurian brachiopods. In: A. Hallam (Editor), Atlas of Palaeobiogeography. Elsevier, Amsterdam, pp. 59-65.

Briden, J.C., 1968. Paleoclimatic evidence of a geocentric axial dipole field. In: R.A. Phinney (Editor), The History of the Earth's Crust, a Symposium. Princeton Univ. Press, pp. 178-194.

Brown, D.A., Campbell, K.S.W. and Crook, K.A.W., 1968. The Geological Evolution of Australia and New Zealand. Pergamon Press, Oxford: $409 \mathrm{pp}$ * *

Bullard, E.C., Everett, J.E. and Smith, A.G., 1965. The fit of the continents around the Atlantic. In: P.M.S. Blackett, E.C. Bullard and S.K. Runcorn (Editors), A Symposium on Continental Drift. Philos. Trans. R. Soc. London, Ser. A, 258:41-51.

Burch fiel, B.C. and Davis, G.A., 1972. Structural framework and evolution of the southern part of the Cordilleran orogen, western United States. Am. J. Sci, 272: 97-118.

Burk, C.A. and Drake, C.L. (Editors), 1974. The Geology of Continental Margins. Springer, New York, N.Y., 1009 pp.

Burrett, C.F., 1974. Plate tectonics and the fusion of Asia. Earth Planet. Sci. Lett., 21 : $181-189$.

Bush, V.A., Vongaz, L.B., Kravehenko, K.N., Sardonnikov, N.M. and Sinitsin, F.Ye, 1970. The interior and exterior troughs of Tien-Shan. Geotectonics, $6: 354-361$.

Campbell, C.J., 1974a. Colombian Andes. In: A.M. Spencer (Editor), Mesozoic and Cenozoic Orogenic Belts: Data for orogenic studies. Scottish Academic Press, Edinburgh, pp. $705-724$.

Campbell, C.J., 1974b. Ecuadorian Andes. In: A.M. Spencer (Editor). Mesozoic and Cenozoic Orogenic Belts: Data for orogenic studies. Scottish Academic Press, Edinburgh, pp. $725-732$.

Carlson, M.P. and Boucot, A.J., 1967. Early Silurian brachiopods from the subsurface of southeastern Nebraska. J. Paleontol., 41: 1121-1125. *

Carter, C. and Laufeld, S., 1975. Ordovician and Silurian fossils in well cores from North Slope of Alaska. Am. Assoc. Pet. Geol, Bull, 59: 457-464.*

Case, J.E., 1974. Major basins along the continental margin of northern South America. In: C.A. Burk and C.L. Drake (Editors), The Geology of Continental Margins. Springer, New York, N.Y., pp. $733-742$.

Chamberlin, T.C., 1877. Geology of eastern Wisco.sin. In: Geology of Wisconsin, II. Wisconsin Geol. Surv., pp. 91-405.*

Chang, C.F. and Cheng, H.L., 1973. Some tectonic features of the Mt. Jolmo Lungma area, southern Tibet, China. Sci. Sin., 14:257-265.

Chlupac, I., 1967. Devonian of Czechoslovakia. In: D.H. Oswald (Editor), International Symposium on the Devonian System, 1. Alberta Soc. Pet. Geol, Alberta, pp. 109-126.

Christie, R.L., 1964. Geological reconnaissance of northeastern Ellesmere Island, District of Franklin. Geol. Surv. Can, Mem., 331: 79 pp. "

Churkin, M., 1965. First occurrence of graptolites in the Klamath Mountains, California. U.S. Geol. Surv., Prof. Pap., 525-C: C72-C73. * 
Churkin, M., 1972. Western boundary of the North American continental plate in Asia. Geol. Soc. Am., Bull., 83: 1027-1036.

Churkin, M., 1973. Paleozoic and Precambrian rocks of Alaska and their role in its structural evolution. U.S. Geol. Surv., Prof. Pap., 740: 64 pp. *

Churkin, M., 1974. Paleozoic marginal ocean basin - Volcanic arc systems in the Cordilleran fold belt. In: R.H. Dott and R.H. Shaver (Editors), Modern and Ancient Geosynclinal Sedimentation. Soc. Econ. Paleontol. Mineral., Spec. Publ., 19: 174-192.

Clark, L.D., Imlay, R.W., McMath, V.E. and Silberling, N.J., 1962. Angular unconformity between Mesozoic and Paleozoic rocks in the northern Sierra Nevada, California. U.S. Geol. Surv., Prof. Pap., 450-B: B15-B19.*

Cobbing, E.J., 1972. Tectonic elements of Peru and the evolution on the Andes. 24 Int. Geol. Congr., Sec. 3, Tectonics, pp. 306-315.

Cocks, L.R.M., 1972. The origin of the Silurian Clarkeia shelly fauna of South America, and its extension to West Africa. Paleontology, 15:623-630.*

Cocks, L.R.M. and McKerrow, W.S., 1973. Brachiopod distributions and faunal provinces in the Silurian and Lower Devonian. In: N.F. Hughes (Editor), Organisms and Continents through Time. Paleontology, Spec. Pap., 12: 291-304.

Cucks, L.R.M., Brunton, C.H.C, Rowell, A.J. and Rust, I.C., 1970. The first Lower Palaeozoic fauna proved from South Africa. Q.J. Geol. Soc. London, 125: 583-603. *

Coleman, P.J. (Editor), 1973. The Western Pacific: island arcs marginal seas, geochemistry. Crane and Russak, New York, and Univ. Western Australia Press, Nedlands, Western Australia: $675 \mathrm{pp}$.

Coleman, R.G., 1972. Blueschist metamorphism and plate tectonics. 24th Int. Geol. Congr., Sec. 2, Petrology, pp. 19-26.

Cowie, J.W., 1961. The Lower Palaeozoic geology of Greenland. In G.O. Raasch (Editor), Geology of the Arctic. Univ. Toronto Press, pp. 160-169. *

De Cserna, Z., 1970. Mesozoic sedimentation, magmatic activity and deformation in northern Mexico. In: K. Seewald and D. Sundeen (Editors), The Geologic Framework of the Chihuahua Tectonic Belt. The West Texas Geol. Soc, Midland, Texas, pp. 99117.

Dewey, J.F., 1969. Evolution of the Appalachian/Caledonian Orogen. Nature, 222: $124-129$.

Dewey, J.F., Pitman, W.C., Ryan, W.B.F. and Bonnin, J., 1973. Plate tectonics and the evolution of the Alpine System. Geol, Soc. Am., Bull., 84 : 3137-3180.

Din'Kat, N., 1972. Types and positions of abyssal fractures in North Vietnam. Int. Geol. Rev., 14: $937-946$.

Douglas, R.J.W., 1970. Geology and economic minerals of Canada. Geol. Surv. Can., Econ. Geol. Rept., 1: 838 pp. *

Eastler, T.W., 1969. Silurian of Change Islands and eastern Notre Dame Bay, Newfoundland. Am. Assoc. Petr. Geol., Mem., 12: 425-432. *

Ehlers, G.M. and Kesling, R.V., 1957. Silurian rocks of the Northern Peninsula of Michigan. Michigan Basin Geol. Soc., Annual Geological Excursion: 63 pp. *

Ehlers, G.M. and Kesling, R.V., 1962. Silurian rocks of Michigan and their correlation. In: Silurian Rocks of the Southern Lake Michigan Area, pp. 1-20. Michigan Basin Geological Society. *

Elliot, D.H., 1975. Tectonics of Antarctica: a review. Am. J. Sci., 275-A: 45-106.

Emelyanov, E.M., Litvin, V.M., Levchenko, V.A. and Martynova, G.P., 1971. The geology of the Barents Sea. In: F.M. Delaney (Editor), The Geology of the East Atlantic Continental Margin, 2 Europe. Inst. Geol. Sci., Rept., 70/14:1-16.

Emery, K.O., 1969. The continental shelves. Sci. Am., 221: 106-122.

Flugel, H.W. and Schonlaub, H.P., 1972. Geleitworte zur stratigraphischen Tabelle des Paläozoikums von Österreich. Verh. Geol. Bundesanst., 2: 187-198. *

Foyn, S, 1967. Stratigraphical consequences of the discovery of Silurian fossils on Mageeroy, the island of North Cape. Nor. Geol. Unders., 247:208-222. * 
Garetsky, R.C., Golov, A.A., Zhuravlev, V.S., Nevolin, N.V., Samodurov, V.I., Fomenko, K.E., Eventov, Ya.S. and Yanshin, A.L., 1972. The Caspian Depression - the deepest depression of old platforms. 24th Int. Geol. Congr., Sect. 3, Tectonies, pp. 348-354.

Gee, D.G., 1975. A tectonic model for the central part of the Scandinavian Caledonides. Am. J. Sci., 275-A: 468-515.

Gillette, T., 1947. The Clinton of western and central New York. New York State Museum, Bull., 341: 191 pp. *

Gobbett, D.J. and Hutchison, C.S., 1973. Geology of the Malay Peninsula. Wiley-Interscience, New York, 438 pp. *

Griffiths, J.R. and Burrett, C.F., 1973. Were Southeast Asia and Indonesia parts of Gondwanaland? Nature, (Phys. Sci.) 245: 92-93.

Hailwood, E.S., 1974. Palaeomagnetism of the Missi Norite (Morocco) and the Paleozoic reconstruction of Gondwanaland. Earth Planet. Sci. Lett., 23: 376-386.

Haller, J., 1971. Geology of the East Greenland Caledonides. Interscience Publishers, Switzerland, $413 \mathrm{pp}$.

Harland, W.B. and Gayer, R.A., 1972. The Arctic Caledonides and earlier oceans. Geol. Mag., 109: 289-314.

Herron, E.M., Dewey, J.F. and Pitman, W.C., 1974. Plate-tectonic model for the evolution of the Arctic. Geology, 2: 377-380.

Hilde, T.W.C. and Wageman, J.M., 1973. Structure and origin of the Japan Sea. In: P.J. Coleman (Editor), The Western Pacific; island arcs, marginal seas, geochemistry. Crane and Kussak, New York, pp. 415-434.

Hill, D., 1958. Distribution and sequence of Silurian coral faunas. J. Proc. R. Soc. New South Wales, 92: 151-173.

Holtedahl, O., 1960. Geology of Norway. Aschehoug, Oslo, 540 pp. *

Huang, T.K., 1960. The main characteristics of the structure of China: preliminary conclusions. Sci. Sin., 11:492-550.

Hunter, R.E., 1970. Facies of iron sedimentation of the Clinton Group. In: G.W. Fisher, F.J. Pettijohn, J.C. Meeb and K.N. Weaver (Editors), Studies of Appalachian Geology: Central and Southern. Interscience, New York, pp. 101-121.

Hutchison, C.S., 1973. Tectonic evolution of Sundaland: a Phanerozoic synthesis. Geol. Soc. Malaysia, Bull., 6: 61-86.

Hutchison, C.S., 1975. Ophiolite in Southeast Asia. Geol. Soc. Am. Bull., 86: 797-806.

Ichikawa, K., 1965. Mobile shelf (Honshu major belt) and outer geosynclinal belts in the Mesozoic and Paleogene. In: M. Minato, M. Gorai and M. Hunahashi (Editors), The Geologic Developments of the Japanese Islands. Tsukiji Shokan, Tokyo, pp. 127-131.

Ivanov, S.N., Perfiliev, A.S., Efimov, A.A., Smirnov, G.A., Necheukhin, V.M. and Fershtater, G.B., 1975. Fundamental features in the structure and evolution of the Urals. Am. J. Sci., 275-A: 107--130.

Izkoh, E.D. and Van Tien, N., 1964. Late geosynclinal ultrabasics of North Vietnam. Dokl. Akad. Sci. Earth Sci. Sect., 155: 56.

Jaanusson, V., 1973. Ordovician articulate brachiopods. In: A. Hallam (Editor), Atlas of Palaeobiogeography. Elsevier, Amsterdam, pp. 19-25.

Jiang, C.F. and Chu, C.C., 1964. On Indosinian movement in the eastern Tsinling Miogeosyncline. Sci. Sin. (Notes), 13:1346-1347.

Johnson, M.E., 1975. Recurrent community patterns in epeiric seas: The Lower Silurian of eastern Iowa. Proc. Iowa Acad. Sci., 82: 130-139. *

Jones, D.L., Irwin, W.P. and Ovenshine, A.T., 1972. Southeastern Alaska -- A displaced continental fragment? U.S. Geol. Surv., Prof. Pap., 800-B: B211-B217.

Kaljo, D., 1972. Facies control of the faunal distribution in the Silurian of the eastern Baltic region. 24th Int. Geol. Congr., Sec. 7, Paleontology, pp. 544-548. *

Kaljo, D. and Klaamann, E., 1973. Ordovician and Silurian corals. In: A. Hallam (Editor), Atlas of Paleobiogeography. Elsevier, Amsterdam, pp. 37-45.

Kay, M., 1969. Silurian of Northeast Newfoundland Coast. In: M. Kay (Editor), North 
Atlantic Geology and Continental Drift. Am. Assoc. Pet. Geol, Mem., 12: 414-424. *

Khalevin, N.I., 1972. Deep structure of the Urals and adjacent regions, from the geophysical data. Geotectonics, 6: 360-366.

Khramov, A.N., Gontscharov, G.I., Commissarova, R.A. et al,, 1974. Paleozoic Paleomagnetism, U.S.S.R. Ministry of Geology, Nedra, Leningrad, 335: 238 pp.

Kimura, T., 1974. The ancient continental margins of Japan. In; C.A. Burk and C.L. Drake (Editors), The Geology of Continental Margins. Springer, New York, pp. 817830.

Kingma, J.T., 1974. The Geological Structure of New Zealand. Wiley, New York, 407 pp.

Kosygin, Yu.A. and Parfenov, L.M., 1975. Structural evolution of eastern Siberia and adjacent areas. Am. J. Sci., 275-A: 187-208.

Kulakov, V.V., 1970. The principal features of the tectonics of western Afghanistan and the adjoining regions. Geotectonics, $1: 45-50$.

Kulikov, P.A., 1970. Foundation of West Siberian Shield in Shaim-Krasnolenin petroliferous region. Int. Geol. Rev., 12: 39-49.

Kulikov, P.K., Belousov, A.P. and Latypov, A.A., 1972. West Siberia Triassic rift system. Geotectonics, 6: 367-371.

Kuno, H., 1966. Lateral variation of basaltic magmas across continental margins and island arcs. In: W.H. Poole (Editor), Continental Margins and Island Arcs. Can. Geol. Surv., Pap., 66-15: 317-336.

Lathram, E.H., 1973. Tectonic framework of northern and central Alaska. Am. Assoc. Pet. Geol., Mem., 19: 351-360.

Lathram, E.H., Grantz, A., Barnes, D.F., Brew, D.A., Ovenshine, A.T., Plafker, G., Detterman, R.L., Foster, H.L., Churkin, M, Patton, W.W., Hoare, J.H., Tailleur, I.L., Brosge, W.P., Miller, T.P. and Sainsbury, C.L., 1974. Alaska. In: A.M. Spencer (Editor), Mesozoic and Cenozoic Orogenic Belts: Data for orogenic studies. Scottish Academic Press, Edinburgh, pp. 563-589.

Laughton, A.S., Sclater, J.G. and McKenzie, D.P., 1973. The structure and evolution of the Indian Ocean. In: D.H. Tarling, and S.K. Runcorn (Editors), Implications of Continental Drift to the Earth Sciences, 1. Academic Press, London: pp. 203-212.

Laurent, R., 1972. The Hercynides of South Europe, a model. 24th Int. Geol. Congr., Sec. 3, Tectonics, pp. 363-370.

Lee, J.S., 1939. The Geology of China. Murby, London, 528 pp. *

Lee, S.M., 1972. Metamorphic facies and facies series in relation to the tectonics of South Korea. 24 th int. Geol. Congr., Sec. 2, Petrology, pp. 81-87.

Lenz, A.C., 1972. Ordovician to Devonian history of the northern Yukon and adjacent district of Mackenzie. Bull. Can. Pet. Geol., 20:321-361. *

Li, S.K. (Editor), 1956. Regional Stratigraphic Table of China (draft). Translated into English, 1958, by Joint Publication Research Service, U.S. Dept. of Commerce, Washington, D.C., J.P.R.S. 18, 538: 511 pp. *

Malfait, B.T. and Dinkelman, M.G., 1972. Circum-Caribbean tectonic and igneous activity and the evolution of the Caribbean plate. Geol. Soc. Am. Bull, 83: 251-272.

Manten, A.A., 1971. Silurian Reefs of Gotland. Developments in Sedimentology 13, Elsevier, Amsterdam: 539 pp. *

Martin, R.G. and Case, J.E., 1975. Geophysical studies in the Gulf of Mexico. In A.E.M. Nairn and F.G. Stehli (Editors), The Ocean Basins and Margins, 3: The Gulf of Mexico and the Caribbean. Plenum, New York, pp. 65-106.

Matti, J.C., Murphy, M.A. and Finney, S.C., 1975. Silurian and Lower Devonian basin and basin-slope limestones Copenhagen Canyon, Nevada. Geol. Soc. Am. Spec. Pap., 159: $48 \mathrm{pp}$.

McBride, E.F. and Thompson, A., 1970. The Caballos Novaculite, Marathon Region, Texas. Geol. Soc. Am. Spec. Pap. 122: 129 pp. *

McElhinnny, M.W., 1973. Palaeomagnetism and Plate Tectonics. Cambridge University Press, $358 \mathrm{pp}$. 
McElhinny, M.W. and Embleton, B.J.J., 1974. Australian palaeomagnetism and the Phanerozoic plate tectonics of eastern Gondwanaland. Tectonophysics, 22:1-29.

McElhinny, M.W. and Opdyke, N.D., 1973. Remagnetization hypothesis discounted: A palaeomagnetic study of the Trenton Limestone, New York State. Geol. Soc. Am. Bull., 84: 3697-3707.

McElhinny, M.W., Embleton, B.J.J., Daly, L. and Pozzi, J.P., 1976. Palaeomagnetic evidence for the location of Madagascar in Gondwanaland. Geology, 4: 455-457.

McKenzie, D.P., Molnar, P. and Davies, S.D., 1970. Plate tectonics of the Red Sea and East Africa. Nature, 226: 243--248.

McKerrow, W.S. and Ziegler, A.M., 1971. The Lower Silurian palaeogeography of New Brunswick and adjacent areas. J. Geol., 79:635-646.*

McKerrow, W.S. and Ziegler, A.M., 1972a. Silurian palaeogeographic development of the Proto-Atlantic Ocean. 24th Int. Geol. Congr., Sect. 6, Stratigraphy and Sedimentology, pp. $4-10$.

McKerrow, W.S. and Ziegler, A.M., 1972b. Palaeozoic oceans. Nature (Phys. Sci.), 240: $92-94$.

Meynen, S.V., 1969. The continental drift hypothesis in the light of Carboniferous and Permian paleoflora. Geotectonics, 5: 289-295.

Moore, J.C., 1974. The ancient continental margin of Alaska. In: C.A. Burk and C.L. Drake (Editors), The Geology of Continental Margins. Springer, New York, pp. 811816.

Mossakovskiy, A.A., 1970. Upper Paleozoic volcanic belt of Europe and Asia. Geotectonics, $4: 247-253$.

Mu, A.T., Wen, S.H., Wang, Y.K. and Chang, P.K., 1973. Stratigraphy of the Mount Jolmo Lumgma region in southern Tibet, China. Sci. Sin., 16:96 111.

Murphy, R.W., 1973. The Manila Trench-West Taiwan foldbelt: a flipped subduction zone. Geol. Soc. Malaysia, Bull., 6: 27-42.

Nairn, E.A.M. and Stehli, F.G. (Fditors), 1973. The Ocean Basins and Margins, 1: The South Atlantic. Plenum, New York, $582 \mathrm{pp}$.

Nairn, A.E.M. and Stehli, F.G. (Editors), 1974. The Ocean Basins and Margins, 2: The North Atlantic. Plenum, New York, 598 pp.

Neumann, G. and Pierson, W.J., 1966. Principles of Physical Oceanography. Prentice-Hall, Englewood Cliffs, N.J., 545 pp.

Nikiforova, O.I. and Obut, A.M., 1965. Stratigraphy of the USSR: Silurian System, X. Nedra, Moscow. *

Nozawa, T., 1972. Isotopic ages of metamorphic rocks and pre-Cretaceous granites in Japanese Islands; a summary in 1972. Bull. Geol. Surv. Japan, 23: 549-571. *

Packer, D.R. and Stone, D.B., 1974. Paleomagnetism of Jurassic rocks from southern Alaska, and the tectonic implications. Can. J. Earth Sci., 11: 976-997.

Packham, G.H., 1973. The speculative Phanerozoic history of the South-West Pacific. In: P.J. Coleman (Editor), The Western Pacific; island ares, marginal scas, gcochemistry. Crane and Russak, New York, pp. 369-388.

Peive, A.V., Perfiliev, A.S. and Ruzhentsev, S.V., 1972. Problems of intracontinental geosynclines. 24 th Int. Geol. Congr., Sect. 3, Tectonics, pp. 486-493.

Pinsak, A.P. and Shaver, R.H., 1964. The Silurian formations of Northern Indiana. Indiana Geol. Surv., Bull., 32: 1--87. *

Piper, J.D.A., 1975. Paleomagnetism of Silurian lavas of Somerset and Gloucestershire, England. Earth Planet. Sci. Lett., 25: 355-360.

Playford, P.E., Cope, R.N., Cockbain, A.E., Low, G.H. and Lowry, D.C., 1975. Phanerozoic, Chapter 2. Geology of Western Australia. Geol. Surv. Western Australia, Mem., 2: $223-436$.

Pojeta, J., Kriz, J. and Berdan, J.M., 1976. Silurian-Devonian pelecypods and Paleozoic stratigraphy of subsurface rocks in Florida and Georgia and related Silurian pelecypods from Bolivia and Turkey. U.S. Geol. Surv. Prof. Pap., 879: 32 pp. 
Pray, L.C., 1953. Upper Ordovician and Silurian stratigraphy of Sacramento Mountains, Otero County, New Mexico. Am. Assoc. Pet. Geol., Bull., 37: 1894-1918. *

Rankin, D.W., 1975. The continental margin of eastern North America in the southern Appalachians: The opening and closing of the proto-Atlantic Ocean. Am. J. Sci., 275-A: 298-336.

Rexroad, C.B., Branson, E.R., Smith, M.G., Summerson, C. and Boucot, A.J., 1965. The Silurian formations of east-central Kentucky and adjacent Ohio. Geol. Surv. Kentucky, Ser. X, Bull. 2, 34 pp. *

Rodgers, J., 1972. L'orogenese avalonienne (fini-precambrian) dans les montagnes des Appalaches. Notes Mem. Serv. Geol. Maroc, 236: 277-286.

Roger, J., 1963. Asie - Republique Populaire Chinoise. Lexique Stratigraphique International, Fasc. 1, vol. I et II, Centre National de la Recherche Scientifique, 1067 pp. *

Rosenberg, V.I., 1969. Thickness of continental crust in the Antarctic. In: Eglazarov (editor), Tectonic Map of Polar Regions of the Earth, Min. Geol. U.S.S.R.

Rozen, O.M., Ivanov, O.D. and Kramarenko, S.M., 1972. Evolution of granites in median massifs (as illustrated by the Kokchetav Massif). Geotectonics, 2: 87-93.

Rutland, R.W.R. and Walter, M.R., 1974. Philippine Archipelago. In: A.M. Spencer (Editor), Mesozoic and Cenozoic Orogenic Belts: Data for Orogenic Studies. Scottish Academic Press, Edinburgh, pp. 491-500.

Sanford, B.V., Norris, A.W, and Bostock, H.H., 1967. Geology of the Hudson Bay Lowlands (Operation Winisk). Geol. Surv. Can., Pap., 67-60: 118 pp. *

Savage, T.E., 1917. Stratigraphy and paleontology of the Alexanderian Series in Illinois and Missouri. State of Illinois, State Geol. Surv, Administrative Report and Economic and Geological Papers, Bull., 23: 67-171.*

Sborshcikov, I.M. and Natapov, L.M., 1968. Dislocations associated with the gypsumanhydrite formation in the West Verkhoyansk Region. Dokl. Akad. Nauk SSSR, 186: $86-89$.

Scholl, D.W., 1974. Sedimentary sequences in North Pacific trenches. In: C.A. Burk and C.L. Drake (Editors), The Geology of Continental Margins. Springer, New York, pp. $493-504$.

Scrutton, R.A. and Roberts, D.G., 1971. Structure of Rockall Plateau and Trough, Northeast Atlantic. In: R.M. Delaney (Editor), The Geology of the East Atlantic Continental Margin, 2, Europe. Inst. Geol. Sci., Rept., 70/14: 77-88.

Seeley, D.R., Vail, P.R. and Walton, G.G., 1974. Trench slope model. In: C.A. Burk and C.L. Drake (editors), The Geology of Continental Margins. Springer, New York, pp. $249-260$.

Seslavinskiy, K.B., 1970. Structure and development of the South Anyui Fault Trough, West Chukotka, Geotectonics, 5: 311-317.

Smith, A.G., Briden, J.C. and Drewry, G.E., 1973. Phanerozoic world maps. In: N.F. Hughes (Editor), Organisms and Continents Through Time. Spec. Pap. Palaeontol., 12: $1-42$.

Sokolowski, S., 1970. Geology of Poland, 1, Stratigraphy, 1, Precambrian and Palaeozoic. Wydawnictwa Geologiczne, $651 \mathrm{pp}$. *

Spencer, A.M. (Editor), 1974. Mesozoic and Cenozoic Orogenic Belts: Data for Orogenic Studies. Scottish Academic Press, Edinburgh, 809 pp.

Stearn, C.W., 1956. Stratigraphy and paleontology of the Interlake Group and Stonewall Formation of Southern Manitoba. Geol. Surv. Can., Mem., 281, 162 pp. *

Stocklin, J., 1974. Possible ancient continental margins in Iran. In: C.A. Burk and C.L. Drake (Editors), The Geology of Continental Margins. Springer, New York, pp. 873888.

Stommel, H., 1948. The westward intensification of wind-driven ocean currents. Trans. Am. Geophys. Union, 29: 202-206.

Stoneley, R., 1974. Evolution of the continental margins bounding a former Southern 
Tethys. In: C.A. Burk and D.L. Drake (Editors), The Geology of Continental Margins. Springer, New York, pp. 889-903.

Talent, J.A., Berry, W.B.N. and Boucot, A.J., 1975. Correlation of the Silurian rocks of Australia, New Zealand, and New Guinea. Geol. Soc. Am., Spec. Pap., 150: 108 pp. *

Teixeira, C. and Thadeu, D., 1967. Le Devonien du Portugal. In: D.H. Oswald (Editor), International Symposium on the Devonian System, I. Alberta Society of Petroleum Geologists, Calgary, pp. 189-199.

Trettin, H.P., 1969. Lower Palaeozoic sediments of northwestern Baffin Island, District of Franklin. Geol. Surv. Can., Bull., 157: 70 pp. *

Twenhofel, W.H., 1928. Geology of Anticosti Island. Geol. Surv. Can., Mem., 154: 481 pp. *

Uchupi, E., 1971. Bathymetric Atlas of the Atlantic, Caribbean, and Gulf of Mexico. Woods Hole Oceanographic Institution, Ref. No. $71-72$ (unpubl. manuscr.).

Udintsev, G.B., 1975. International Indian Ocean Expedition (IIOE) Geological-Geophysical Atlas: $168 \mathrm{pp}$. (Distributed by Pergamon Press.)

Van der Voo, R., Mauk, F.J. and French, R.B., 1976. Permian-Triassic continental configurations and the origin of the Gulf of Mexico. Geology, 4: 177-180.

Viniegra-Osorio, F., 1971. Age and evolution of salt basins of southeastern Mexico. Bull. Am. Assoc. Pet. Geol., 5: 478-494.

Vinogradov, A.P. (Editor), 1968. Atlas of the Lithological-Paleogeographical Maps of the U.S.S.R., 1, Min. Geol. U.S.S.R. Acad. Sci. U.S.S.R., Moscow. *

Vinogradov, A.P. (Editor), 1969. Atlas of the Lithological-Paleogeographical Maps of the U.S.S.R., 2, Min. Geol. U.S.S.R. Acad. Sci. U.S.S.R., Moscow.

Visser, W.A. and Loffler, E., 1975. New Guinea. In: R.W. Fairbridge (Editor), The Encyclopedia of World Regional Geology, I: Western Hemisphere (including Antarctica and Australia). Halsted, Stroudsburg, Pa., pp. 372-383.

Walter, R., 1972. Palaeogeographie des Siluriums in Nord-, Mittel- und Westeuropa. Geotek tonische Forsch., 41: 180 pp. *

Wanless, R.K., Stevens, R.D., Lachance, G.R. and Edmonds, C.M., 1967. Age determinations and geological studies, $\mathrm{K}-\mathrm{Ar}$ isotopic ages. Geol. Surv. Can., Pap., 66-17, Rep. 7: 120 pp. *

Waterhouse, J.B., 1975. The Rangitata orogen. Pacif. Geol., 9: 35-73.

Whittington, H.B. and Hughes, C.P., 1972. Geography and Faunal Provinces in the Tremadoc Epoch. In: C.A. Ross (Editor), Paleogeographic Provinces and Provinciality. Soc. Econ. Paleontol. Mineral., Spec. Publ., 21: 203-218.

Williams, A., 1973. Distribution of brachiopod assemblages in relation to Ordovician paleogeography. In: N.F. Hughes (Editor), Organisms and Continents Through Time. Spec. Pap. Palaeontol., 12: 241-269. *

Williams, H., 1973. Bay of Islands Map-Area, Newfoundland. Geol. Surv. Can., Pap., 72-34: 7 pp. *

Willman, H.B., 1973. Rock stratigraphy of the Silurian system in northeastern and northwestern Illinois. Illinois State Geol. Surv., Circ., 479: 55 pp. *

Wilson, J.L. and Majewske, O.P., 1960. Conjectured Middle Paleozoic history of central and west Texas. In: F.G. Conselman (Fditor), Aspects of the Geology of Texas: A symposium. Texas Univ. Bur. Econ. Geol., Publ. 6017: 65-86. *

Wolfart, V.R., 1967. Zur Entwicklung der paläozoischen Tethys in Vorderasien. Erdoel Kohle, Erdgas, Petrochem., 20: 168-180.*

Wright, J.E., Sinha, A.K. and Glover III, L., 1975. Age of zircons from the Petersburg Granite, Virginia: with comments on belts of plutons in the Piedmont. Am. J. Sci., 275: 848-862.

Yegorkin, A.V. and Matushkin, B.A., 1970. Crustal structure of the Caucasus and western central Asia based on geophysical sounding data. Int. Geol. Rev., 12: 281-290.

Yungul, S.H., 1971. Magnetic anomalies and the possibilities of continental drifting in the Gulf of Mexico. J. Geophys. Res., 76: 2639-2642. 
Ziegler, A.M., 1970. Geosynclinal development of the British Isles during the Silurian period. J. Geol., 78: 445-479. *

Ziegler, A.M., 1972. Some points of interest concerning the Silurian inliers of southwest central Ireland in their geosynclinal context: a reply. J. Geol. Soc. London, 128: $263-266$.

Ziegler, A.M., Boucot, A.J. and Sheldon, R.P., 1966. Silurian pentameroid brachiopods preserved in position of growth. J. Paleontol., 40:1032-1036. *

Ziegler, A.M., Cocks, L.R.M. and Bambach, R.K., 1968. The composition and structure of Lower Silurian marine communities. Lethaia, 1: 1-27.

Ziegler, A.M., Rickards, R.B. and McKerrow, W.S., 1974. Correlation of the Silurian rocks of the British Isles. Geol. Soc. Am. Spec. Pap., 154: 154 pp.

Zijderveld, J.D.A. and Van der Voo, R., 1973. Palaeomagnetism in the Mediterranean Area. In: D.K. Tarling and S.K. Runcorn (Editors), Implications of Continental Drift to the Earth Sciences, 1. Academic Press, London, pp. 133-161.

Zonenshain, L.P., 1973. The evolution of central Asiatic geosynclines through sea-floor spreading. Tectonophysics, 19: 213-232.

Zonenshain, L.P., Markova, N.G. and Nagibina, M.S., 1971. Relationship between the Paleozoic and Mesozoic structures of Mongolia. Geotectonics, 4: 229-233. 